\title{
Geologic Map of the Santa Barbara Coastal Plain Area, Santa Barbara County, California
}

By Scott A. Minor, ${ }^{1}$ Karl S. Kellogg, ${ }^{1}$ Richard G. Stanley, ${ }^{2}$ Larry D. Gurrola, ${ }^{3}$

Edward A. Keller, and Theodore R. Brandt ${ }^{1}$

'U.S. Geological Survey, Denver, Colo.

2U.S. Geological Survey, Menlo Park, Calif.

${ }^{3}$ Consulting Geologist, Santa Barbara, Calif.

${ }^{4}$ Department of Earth Science, University of California, Santa Barbara, Calif.

Pamphlet to accompany

Scientific Investigations Map 3001 



\section{Geologic Map of the Santa Barbara Coastal Plain Area, Santa Barbara County, California}

By Scott A. Minor, ${ }^{1}$ Karl S. Kellogg, ${ }^{1}$ Richard G. Stanley, ${ }^{2}$ Larry D. Gurrola ${ }^{3}$

Edward A. Keller, ${ }^{4}$ and Theodore R. Brandt ${ }^{1}$

'U.S. Geological Survey, Denver, Colo.

2U.S. Geological Survey, Menlo Park, Calif.

${ }^{3}$ Consulting Geologist, Santa Barbara, Calif.

${ }^{4}$ Department of Earth Science, University of California, Santa Barbara, Calif.

Pamphlet to accompany

Scientific Investigations Map 3001 


\title{
U.S. Department of the Interior \\ KEN SALAZAR, Secretary
}

\author{
U.S. Geological Survey \\ Suzette M. Kimball, Acting Director
}

U.S. Geological Survey, Reston, Virginia: 2009

For product and ordering information:

World Wide Web: http://www.usgs.gov/pubprod

Telephone: 1-888-ASK-USGS

For more information on the USGS--the Federal source for science about the Earth, its natural and living resources, natural hazards, and the environment:

World Wide Web: http://www.usgs.gov

Telephone: 1-888-ASK-USGS

Any use of trade, product, or firm names is for descriptive purposes only and does not imply endorsement by the U.S. Government.

Although this report is in the public domain, permission must be secured from the individual copyright owners to reproduce any copyrighted materials contained within this report.

Suggested citation:

Minor, S.A., Kellogg, K.S., Stanley, R.G., Gurrola, L.D., Keller, E.A., and Brandt, T.R., 2009, Geologic Map of the Santa Barbara Coastal Plain Area, Santa Barbara County, California: U.S. Geological Survey Scientific Investigations Map 3001, scale 1:25,000, 1 sheet, pamphlet, 38 p. 


\section{Contents}

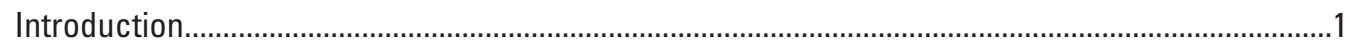

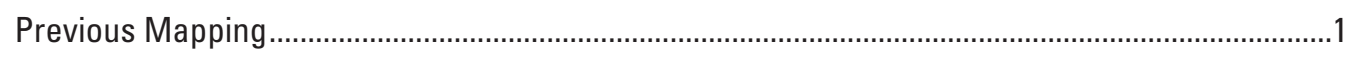

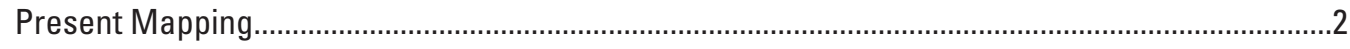

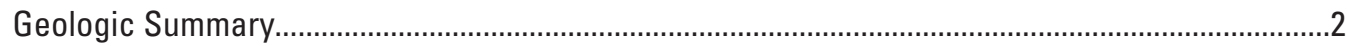

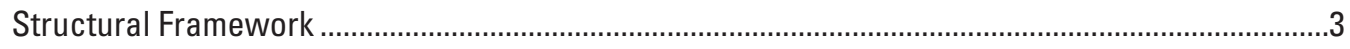

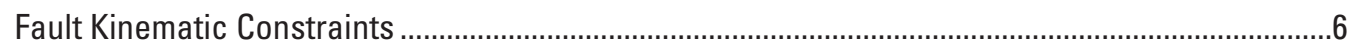

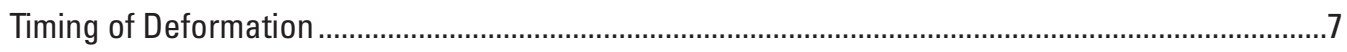

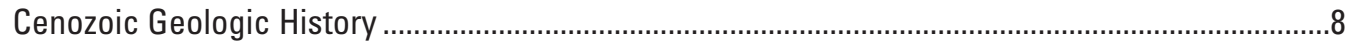

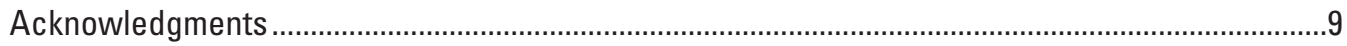

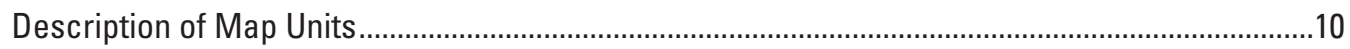

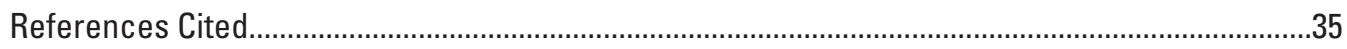




\section{Conversion Factors}

\begin{tabular}{lll}
\hline To convert & Multiply by & To obtain \\
\hline meter $(\mathrm{m})$ & 3.281 & foot $(\mathrm{ft})$ \\
kilometer $(\mathrm{km})$ & 0.6214 & mile $(\mathrm{mi})$ \\
square kilometer $\left(\mathrm{km}^{2}\right)$ & 0.3861 & square mile $\left(\mathrm{mi}^{2}\right)$ \\
\hline
\end{tabular}




\section{Introduction}

This report presents a newly revised and expanded digital geologic map of the Santa Barbara coastal plain area (fig. 1) at a compilation scale of 1:24,000. ${ }^{1}$ The map depicts the distribution of bedrock units and surficial deposits and associated deformation underlying and adjacent to the coastal plain within the contiguous Dos Pueblos Canyon, Goleta, Santa Barbara, and Carpinteria 7.5-minute quadrangles (fig. 2). The new map supersedes an earlier preliminary geologic map of the central part of the coastal plain (Minor and others, 2002; revised 2006) that provided coastal coverage only within the Goleta and Santa Barbara quadrangles. In addition to new mapping to the west and east, geologic mapping in parts of the central map area has been significantly revised from the preliminary map compilation - especially north of downtown Santa Barbara in the Mission Ridge area - based on new structural interpretations supplemented by new biostratigraphic data. Several new map units recognized in the areas of expanded mapping are described. Abundant new biostratigraphic and biochronologic data based on microfossil identifications are presented in expanded unit descriptions of the marine Neogene Monterey and Sisquoc Formations. Sitespecific fault kinematic observations embedded in the digital map database are more complete owing to the addition of slipsense determinations. Finally, the present report includes an expanded and refined summary of stratigraphic and structural observations and interpretations that are based on the composite geologic data contained in the new map compilation (see Geologic Summary below). The digital geologic database for this map is available on the Internet at: http://pubs.usgs.gov/ $\operatorname{sim} / 3001$.

The Santa Barbara coastal plain is located in the western Transverse Ranges physiographic province along an east-westtrending segment of the southern California coastline about $100 \mathrm{~km}$ northwest of Los Angeles (fig. 1). The coastal plain is defined here as the relatively low elevation (lower than 150 to $300 \mathrm{~m}$, depending on location), low- to moderate-relief piedmont that generally slopes gently seaward from the steep Santa Ynez Mountains range front on the north to the Santa Barbara Channel on the south (figs. 3, 4, and 5). The maximum width of the coastal plain is about $7 \mathrm{~km}$ near the cities of Santa Barbara and Goleta, and narrows to $3 \mathrm{~km}$ or less several kilometers west of Goleta and near Carpinteria (figs. 2 and 6). The coastal plain surface includes several mesas and hills (figs. 3, 4, and 6) that are geomorphic expressions of potentially active folds and partly buried oblique and reverse faults of the Santa Barbara fold and fault belt that transects the coastal plain (SBFFB, fig. 2) (Keller and Gurrola, 2000; Gurrola

${ }^{1}$ The map and database were compiled at a scale of 1:24,000, but the printed map scale is 1:25,000 due to printing press size limitations. and others, 2001). [Note: Although Keller and Gurrola (2000) and Gurrola and others (2001) named the structural belt the "Santa Barbara Fold Belt", we refer to it as a "fold and fault belt" due to the common presence of both surficial folds and faults along it.] Strong earthquakes have occurred offshore within $10 \mathrm{~km}$ of the Santa Barbara coastal plain in 1925 (6.3 magnitude), 1941 (5.5 magnitude), and 1978 (5.1 magnitude). These, and numerous smaller seismic events located beneath and offshore of the coastal plain, likely occurred on reverseoblique-slip faults that are similar to, or continuous with, Quaternary reverse faults crossing the coastal plain (Yerkes and Lee, 1987). Thus, faults of the SBFFB pose a significant earthquake hazard to the approximately 200,000 people living within the major coastal population centers of Santa Barbara, Goleta, and Carpinteria. In addition, numerous Quaternary landslide deposits along the steep southern flank of the Santa Ynez Mountains (Bezore and Wills, 2000) indicate the potential for continued slope failures and mass movements in developed areas. Folded, faulted, and fractured sedimentary rocks in the subsurface of the coastal plain and adjacent Santa Barbara Channel are sources and reservoirs for economic deposits of oil and gas (Tennyson and Isaacs, 2001), some of which are currently being extracted offshore. Shallow, localized, sedimentary aquifers underlying the coastal plain provide limited amounts of water for the urban areas, but the quality of some of this ground water is compromised by coastal salt-water contamination (Upson, 1951; Muir, 1968). The present map compilation provides a set of uniform geologic digital coverages and shape files that can be used for analysis and interpretation of these and other geologic hazards and resources in the coastal plain region.

\section{Previous Mapping}

The first geologic map produced in the Santa Barbara coastal plain area was a 1:62,500-scale map of the Summerland Oil District by Arnold (1907). Willis (1925) produced the first fault map of the entire coastal plain area at a scale of 1:62,500 as part of an investigation of the large Santa Barbara earthquake of 1925. A second early fault map of the coastal plain (providing coverage as far east as Santa Barbara) was produced by Hill (1932) at a scale of 1:125,000 in conjunction with a structural study of faulting in the area. The earliest systematic geologic mapping in the study area was by Upson (1951), who mapped the coastal plain region in reconnaissance at a scale of 1:31,680 as part of a water-resource study, and by Lian (1954), who mapped the eastern Mission RidgeMontecito area at a scale of 1:62,500. Thomas W. Dibblee, Jr., (1966) produced the first comprehensive, detailed geologic maps of the Santa Barbara coastal plain region. These maps provided geologic coverage of the west half of the map area at a scale of 1:62,500 and of the east half at a scale of 1:31,680. 
Muir (1968) compiled a simplified geologic map of the Santa Barbara-Montecito area as part of a reconnaissance ground-water study that was based mainly on the earlier mapping of Upson and Dibblee. Hoover (1978) mapped the geology of the city of Santa Barbara at a scale of 1:12,000 to evaluate geologic hazards in the Santa Barbara area. As an aid to constructing subsurface geologic interpretations of the coastal-plain region, Olson (1982) produced a 1:24,000-scale geologic map compilation of the area that was largely based on the previous mapping listed above. The Thomas Dibblee Foundation published separate geologic maps of the Carpinteria, Santa Barbara, Dos Pueblos, and Goleta 7.5-minute quadrangles (Dibblee, 1986a, 1986b, 1987a, 1987b) at a scale of 1:24,000, which were largely based on geologic mapping compiled for the earlier Dibblee (1966) maps. The California Geological Survey (formerly California Division of Mines and Geology) produced 1:24,000-scale landslide inventory and landslide potential maps of the Santa Barbara coastal plain region (Bezore and Wills, 2000). Finally, our recent preliminary geologic map of the central part of the coastal plain (Goleta and Santa Barbara quadrangles) (Minor and others, 2002; revised 2006) provided an initial revised geologic depiction of the coastal region and formed a framework for producing the present map.

\section{Present Mapping}

The present geologic compilation of the Santa Barbara coastal plain, along with the preliminary compilation that preceded it (Minor and others, 2002), comprise new, original mapping based on field and aerial-photograph geologic observations and interpretations made at the ground surface or in shallow surface excavations, supplemented by new biostratigraphic identifications. In keeping with this surficial theme, and owing to the questionable or conflicting stratigraphic picks in many of the petroleum industry drilling logs in the map area, no geologic cross sections are presented herein. The recently revised geologic time scale of the U.S. Geological Survey Geologic Names Committee (2007) was adopted for assigning geologic ages to map units in this report. In the description of map units, sedimentary lithologic terms and rock naming conventions are largely from Williams and others (1982).

The present mapping results were achieved through the collaborative efforts of geologists with the U.S. Geological Survey (USGS) Southern California Areal Mapping Project (SCAMP) (Minor, Kellogg, and Stanley) and the tectonic geomorphology research group at the University of California at Santa Barbara (Gurrola and Keller). Field-based geologic mapping and associated investigations in the map area were conducted chiefly in 2000 through 2005. Minor and Kellogg conducted most of the geologic mapping inland of the sea cliffs, with Minor's efforts focused on the coastal piedmont and lower flanks of the Santa Ynez Mountains in the Goleta, Santa Barbara, and Carpinteria quadrangles and Kellogg's mapping concentrated in the Dos Pueblos quadrangle and the more mountainous, northern parts of the Goleta and Carpinteria quadrangles. Minor also conducted most of the fault kinematic observations and measurements in the map area. Stanley chiefly mapped and documented stratigraphic details of the Miocene and Pliocene marine rocks exposed along the sea cliffs in all four of the component 7.5-minute quadrangles. Earlier and concurrent mapping and geochronologic, geomorphic, and paleoseismic investigations of locally deformed coastal Quaternary deposits and marine terraces by Gurrola and Keller provided a working model of the Quaternary stratigraphic framework and structural style on the coastal plain, which, in turn, significantly influenced our geologic interpretations during the mapping campaign. T.R. Brandt assisted in the design and editing of the GIS database and performed database integration.

Although our new geologic compilations of the Santa Barbara coastal plain area broadly resemble the earlier Dibblee (1966, 1986a, 1986b, 1987a, 1987b) mapping that has served as the principal geologic map reference in the area, they differ significantly in the amount of stratigraphic and structural detail and the geologic interpretations and map depictions that result from this detail. In particular, new biostratigraphic and (or) lithologic criteria are established for differentiaing the Sisquoc Formation and subunits of the Monterey and Sespe Formations, resulting in marked changes in the mapped positions of contacts for these units. The present compilation includes a more detailed description, differentiation, and mapping of upper Pliocene and Pleistocene marine and nonmarine units that bear on the Quaternary tectonic uplift and deformational history of the coastal plain region and the attendant interplay of marine and continental deposition. Structures are mapped in considerably greater detail than on the Dibblee maps, resulting in a more thorough and, in places, distinct documentation of faults and folds in Quaternary deposits underlying the coastal plain. Numerous fault attitude and kinematic data acquired during the present mapping campaign provide new constraints on the geometry and movement history of both mapped and outcrop-scale faults.

\section{Geologic Summary}

The western Transverse Ranges consist mainly of variably deformed marine and nonmarine sedimentary rocks and deposits that range in age from Jurassic to the present. These strata record a long history of continental-margin sedimentation, and deposits as young as middle Pleistocene record considerable protracted deformation that includes Neogene and Quaternary transpressional faulting, folding, and clockwise vertical-axis rotations of crustal blocks (for example, Dibblee, 1966, 1982; Hornafius and others, 1986; Namson and Davis, 1988; Luyendyk, 1991; Dickinson, 1995; Gurrola and others, 2001). A dramatic result of this deformation is the prominent Santa Ynez Mountains directly north of the Santa Barbara coastal 
plain (fig. 5), which were uplifted along a large homoclinal to anticlinal structure beginning in the Pliocene (Dibblee, 1982).

In the map area, the oldest stratigraphic units consist of Eocene resistant, southward-dipping to overturned, mostly marine sedimentary rocks along the south flank of the Santa Ynez Mountains uplift, which form a backdrop of prominent hogbacks and cuestas adjacent to the Santa Barbara coastal plain (fig. 5). Less resistant but similarly deformed, Oligocene through Pliocene terrestrial and marine sedimentary rocks are exposed in the lower Santa Ynez foothills and in the coastal hills and sea cliffs farther south (fig. 7). Moderately faulted and folded or warped Pleistocene marine and terrestrial sediments underlie many of the hills and mesas on the coastal plain (figs. 8, 9, and 10), and undisturbed uppermost Pleistocene and Holocene surficial deposits directly underlie much of the low-lying coastal plain area and are locally present along the lower flanks of the Santa Ynez Mountains.

Details regarding the structural framework, fault kinematic observations, and timing of deformation in the Santa Barbara coastal plain area are given in the sections below. These are followed by a summary of the Cenozoic geologic history of the area that is based on mapped structural and stratigraphic relations described below and in the Description of Map Units, supplemented by previously reported regional geologic observations and interpretations.

\section{Structural Framework}

Structurally, the Santa Barbara coastal plain area is dominated by the Santa Barbara fold and fault belt (SBFFB) and the overlapping Santa Ynez Mountains uplift (fig. 2). The SBFFB is an east-west-trending zone of potentially active folds and partly blind oblique-slip reverse and thrust faults that spans the entire coastal plain and widens northwestward into the lower southern flank of the Santa Ynez Mountains (figs. 2 and 11) (Keller and Gurrola, 2000; Gurrola and others, 2001). The dominant trend of individual structures within the belt is west-northwest-slightly oblique to the trend of the overall fold and fault belt (figs. 2 and 11). Two major fault systems on the coastal plain that partly define this structural trend are the Mission Ridge fault zone north of Montecito and Santa Barbara, and the Arroyo Parida fault located on the north side of the lower ridge north of Carpinteria. A third major fault system is the More Ranch, which trends east-northeast across the coastal plain oblique to the SBFFB. Other notable west-northweststriking faults of the SBFFB on the coastal plain are, from east to west, the Carpinteria, Rincon Creek, Loon Point, Ortega Hill, Lagoon, Rocky Nook, Mesa, Lavigia, Foothill Road, San Pedro, Carneros, El Encanto, and Isla Vista faults (fig. 11).

The 11-km-long and 0.6- to 1.2-km-wide Mission Ridge fault zone is expressed by as many as three, dominantly southside-up, partly blind, reverse-dextral and reverse-sinistral oblique-slip (based on slickenlines) fault strands and adjacent (on south side) anticlinal upwarps that deform units as young as late Pleistocene (Qoa). This broad fault zone has subtle to dramatic geomorphic expression in the form of fault and fold scarps and upwarps that culminates in the 150- to 200-m-high Mission Ridge anticline upwarp north of downtown Santa Barbara (fig. 4). In contrast, the Arroyo Parida fault consists of a single fault strand that mostly displaces Oligocene age and older bedrock units (Tspm, Tspl, Tcw) in the map area, but youthful movement is suggested by sinistral deflections of stream channels where they cross the fault trace (Gurrola and others, 2001) and by offset late Pleistocene fluvial terraces (Qia) along Santa Monica Creek north of Carpinteria and 30 $\mathrm{km}$ farther east near the end of the Arroyo Parida fault in the Ojai Valley area (Rockwell and others, 1984). The sinistral stream deflections are consistent with sinistral strike-slip slickenlines observed along the Arroyo Parida fault; however, the fault, like many other SBFFB faults, probably has a complex slip history including early normal-slip and later reverseoblique, down-to-the-north movement (see fault kinematic discussion below).

The More Ranch fault system, which spans about 20 $\mathrm{km}$ of the central and western coastal plain (fig. 3), strikes anomalously east-northeast obliquely ( $40^{\circ}$ to $60^{\circ}$ angle) across the dominant west-northwest structural grain of the fold and fault belt (fig. 11). Only a few other, relatively small tracelength faults strike northeast similar to the More Ranch in the coastal plain area, and only one of these - the Fernald Point fault in the eastern map area - may have a similar magnitude of displacement. The More Ranch fault system consists of five distinct parts: (1) an eastern right-stepping en echelon segment that tips out on the crest of Mission Ridge; (2) a northeastern splay that strikes northeast into bedrock in lower San Roque Canyon; (3) a central (between Laguna Blanca area and Mescalitan Island), concealed, single-trace segment; (4) a western right-stepping en echelon "north branch" that projects offshore; and (5) a western, single-trace "south branch" that probably dies out just short of the sea cliffs. The westernmost north branch of the More Ranch fault system clearly exhibits a south-dipping reverse-fault geometry, including a hangingwall anticline formed in capping marine-terrace deposits $(\mathrm{Omt})$, where it is exposed in a sea cliff near the mouth of Bell Canyon and where it was observed in a trench excavation a short distance to the east (Keller and Gurrola, 2000; Gurrola and others, 2001). Segments of the More Ranch farther east similarly have experienced youthful, large south-side-up reverse movement based on the common presence of northfacing scarps where More Ranch fault strands cut middle to upper Pleistocene alluvial (Ooa) and marine-terrace ( $\mathrm{Omt}$ ) deposits. Assuming minimal erosional degradation, scarp heights suggest that maximum cumulative post-early Pleistocene throw along the fault may exceed $75 \mathrm{~m}$ at the east end of Goleta Valley near Laguna Blanca (fig. 3). In comparison, in the subsurface, vertical offset along the central fault segment of lower Pliocene (Tsq) and lower sedimentary units that unconformably underlie the Pleistocene deposits may exceed $600 \mathrm{~m}$ (Olson, 1982). Slickenlines measured at the western sea-cliff fault exposure suggest that the More Ranch has 
experienced reverse-sinistral oblique slip, with the ratio of reverse: sinistral components of slip ranging from about 2:1 (Gurrola and others, 2001) to 1:2 (this study). Significant sinistral components of slip along the More Ranch fault system is corroborated by: (1) a west-northwest-trending anticlinal upwarp localized adjacent to the central fault trace at the west end of More Mesa; (2) 150 m of sinistral strike separation of the upper and lower contacts of the Vaqueros Formation (Tv) across the northeastern fault splay in lower San Roque Canyon; and (3) the right-stepping, en echelon fault traces along the easternmost and westernmost More Ranch fault segments that, if viewed as large Riedel (R) shears, are consistent with sinistral-sense bulk simple shear (Tchalenko, 1970).

In their assessment of earthquake hazards in the SBFFB, Keller and Gurrola (2000) and Gurrola and others (2001) suggested a possible scenario where the Arroyo Parida fault, Mission Ridge fault zone, and More Ranch fault system (collectively referred to by them as the "Mission Ridge fault system") could jointly rupture in a future large ( $\sim 7.0$ magnitude) earthquake. However, such a multiple fault-rupture event seems unlikely given that: (1) the western end of the Arroyo Parida fault projects about $1 \mathrm{~km}$ north of the Mission Ridge fault zone, and the latter appears to be largely truncated to the east by the concealed northeast-striking, down-to-northwest, sinistral-separation Fernald Point fault; (2) the Arroyo Parida fault dips $55^{\circ}$ north at an exposure east of Toro Canyon Creek (also see Jackson and Yeats, 1982), opposite to the inferred south dips of the blind main Mission Ridge reverse fault strands; (3) the Mission Ridge fault zone continues to the west-northwest as much as $3 \mathrm{~km}$ past where the easternmost segment of the More Ranch fault system intersects it (Anderson, 1999); and (4) the More Ranch and Mission Ridge fault zones differ in strike by $30^{\circ}$ where they intersect at Mission Ridge (fig. 11). Potential earthquake scenarios involving separate ruptures on individual Arroyo Parida, Mission Ridge, or More Ranch fault segments seem most consistent with the distinct geometries of these structures.

On the coastal plain, several west-northwest-trending folds within the older and intermediate alluvial (Qoa and $\mathrm{Qia})$ and marine terrace $(\mathrm{Qmt})$ deposits have subtle to strong geomorphic expression that is consistent with a youthful age of deformation; commonly anticlines are coincident with elongate ridges or hills whereas synclines coincide with valleys or swales (figs. 8 and 9) (Keller and others, 1999; Gurrola and others, 2001). One of the most dramatic examples of such a geomorphic-structural correlation is western Mission Ridge just north of downtown Santa Barbara, which is coincident with an anticline that is paired on its north side with an inferred syncline (fig. 11) that roughly follows a linear valley containing the old Sheffield Reservoir site and Mountain Drive. Another is the anticline in the hanging-wall block of the Loon Point thrust fault that forms a small hill where the fold is spectacularly exposed in a sea cliff east of Summerland (fig. 8). Such anticlines and synclines, which are geomorphically and structurally well expressed in Pleistocene alluvial deposits but which commonly have poor structural definition in underlying, discordant bedrock units, are mapped as upwarps and downwarps, respectively (fig. 11). On the basis of several lines of geomorphic evidence, Keller and others (1999) inferred that the Mission Ridge anticline, or upwarp, is a fault-related fold that has propagated westward, reflecting westward propagation of a blind strand of the Mission Ridge fault zone and resulting in progressive westward deflection of Mission Creek. The Lavigia fault, which thrusts Miocene rocks ( $\mathrm{Tr}, \mathrm{Tml})$ northward over Pleistocene deposits of the Santa Barbara Formation (Qsb) in the coastal hills of the Hope Ranch-La Mesa area, is inferred to become blind beneath Santa Barbara deposits along its easternmost $2 \mathrm{~km}$ where its surface expression consists of a closely spaced anticline-syncline pair. Similar blind reverse or thrust faults are inferred to underlie the folds at Ortega Hill, Santa Barbara Cemetery (fig. 9), and the small hills just south of Cathedral Oaks Road and west of Maria Ygnacio Creek in Goleta Valley (for example, southeast projection of the San Pedro fault) (fig. 11) (Gurrola and others, 2001). Several fold axes on the coastal plain are parallel to adjacent traces of faults that have broken through (or nearly so) to the surface, and in such cases the fold on the apparent upthrown, hanging-wall side of the fault is typically an asymmetric anticline or upwarp whose steeper limb dips towards the fault trace. The fault planes, where exposed, typically dip moderately to steeply in directions opposite to the vergences of the adjacent folds. Such structural geometry is consistent with fault-propagation folding (Suppe, 1985). Such anticline-fault associations include those along the Loon Point fault (fig. 8), several strands of the Mission Ridge fault zone (Montecito Valley and eastern Mission Ridge area), the 6-km-long western surface trace of the Lavigia fault, a northwestern segment of the Mesa fault (near Las Positas Road), the eastern strand of the Foothill Road fault (northeastern part of Goleta Valley), and the north branch of the More Ranch fault system (coastal mesa near Ellwood). Where such faults displace Pleistocene alluvial units, the actual fault planes are rarely exposed due to the weak consolidation of the surrounding deposits. Commonly in such cases, however, the faults are well expressed by fold scarps formed by the steep forelimbs of the anticlinal upwarps adjacent to the fault trace. Examples of such fold scarps are along strands of the Carpinteria fault, eastern Mission Ridge fault zone, eastern and northeastern More Ranch fault segments, and the Foothill Road fault. The majority of folds in the coastal plain area have northward vergence, suggesting that most associated blind reverse and thrust faults are dominantly southward dipping similar to the exposed faults and, thus, have accommodated northward components of tectonic transport of their hangingwall blocks. One exception is the southward-verging fold exposed in the sea cliff just south of Santa Barbara Cemetery (fig. 9).

A few faults on the coastal plain along the SBFFB trend merit additional comment. In the Carpinteria area near the east end of the coastal plain, the Carpinteria and Rincon Creek faults are mostly concealed beneath young alluvial deposits 
(Qac), but they are geomorphically well expressed just east of the map area by locally prominent north-facing fault-fold scarps and broad anticlinal upwarps formed in upper Pleistocene deposits (Qca, Qoa, Qmt) on their southern, upthrown blocks. Both structures are south-dipping reverse obliqueslip faults where they are exposed in the Pleistocene deposits in this area. To the west, the Rincon Creek fault continues offshore for several kilometers and accommodates large vertical displacement of Tertiary rocks that are folded into an anticline on the hanging-wall (south) side (Jackson and Yeats, 1982). Farther west, the Mesa fault strikes southeast under young alluvial deposits (Qac) in southwestern downtown Santa Barbara to the shoreline at Stearns Wharf, where possibly the fault continues offshore (fig. 4). Overturned, steeply south-dipping beds of the Sespe Formation (Tspu) that are exposed in the downtown area on a small, isolated hillock just south of the concealed fault trace suggest the presence of a mostly concealed, overturned, northeast-vergent anticline in bedrock in the upthrown Mesa fault block. This inferred fold is similar to, and may be structurally linked with, a northeastvergent anticlinal upwarp in Pleistocene marine and alluvial deposits (Qsb, Qoa) located to the northwest just south of the Mesa fault trace near where it crosses Las Positas Road. On the basis of these anticlines, exposures of structurally elevated Tertiary bedrock (Tspu, Tv) south of the northwest and southeast ends of the onshore fault trace, and small reverse-slip faults observed in upper to middle Pleistocene older alluvial deposits (Qoa) in the Mesa fault zone at its northwest end, we infer that the Mesa is a southwest-dipping reverse or obliquereverse fault that has been active as recently as late Pleistocene time.

Northeast of downtown Santa Barbara, the steep southern front of Mission Ridge between Sycamore Canyon and Montecito Creek is coincident with the west-northwest-striking Lagoon fault, which is a moderately north-dipping reversedextral oblique-slip fault that at the surface places rocks as old as late Miocene (Tmu) over alluvial deposits as young as late Pleistocene (Qoa, Qia?). The Lagoon fault bends into a northwest strike at the mouth of Sycamore Canyon and is inferred to continue to the northwest across and beyond the western nose of Mission Ridge based on an apparent south-facing fault scarp formed in older alluvial deposits (Coa) on the ridge flank. The similar-striking Rocky Nook fault, which lacks geomorphic expression, is inferred to branch off the Lagoon fault beneath older alluvial deposits near Franceschi Park and continue to a small bedrock exposure of the fault along Mission Creek at Rocky Nook Park. There the fault is steeply north-dipping, exhibits reverse-dextral oblique-slip indicators, and places lower Miocene rocks (Tr) over upper Miocene rocks (Tsq) with about 300-500 m of stratigraphic separation. The fault may continue northwest, beneath Mission Creek and the Mission debris-flow deposit (Qdf), and flatten into a north-dipping thrust fault that places Miocene rocks of the Monterey Formation ( $\mathrm{Tml}$ ) over older alluvial deposits ( $\mathrm{Coa}$ ) southeast of Lauro Canyon Dam, which would imply younger (late Pleistocene?) displacement along the western thrust seg- ment of the Rocky Nook. More likely, the Rocky Nook fault links to the west with a steeply southwest-dipping fault that: (1) displaces lower Monterey bedrock (Tml) with 90-275 m of up-to-northeast stratigraphic separation just east of Lauro Canyon Dam; (2) contains possible fault slivers of Qoa gravel where it passes directly beneath the dam (Anderson, 1999); and (3) forms a possible southwest-facing fault-fold scarp in older alluvial deposits ( $\mathrm{Ooa}$ ) where the fault trace crosses San Roque Road just west of the dam. The Lagoon-Rocky Nook fault trend and the neighboring Mission Ridge fault zone to the north collectively may be viewed as a single, broad system of relatively closely spaced northwest-striking reverse obliqueslip faults and folds that has been active as recently as the late Pleistocene. The two fault systems differ, however, in that the upthrown blocks and dip directions of the Lagoon-Rocky Nook faults are to the north, whereas the upthrown blocks and, presumably, dip directions of the main Mission Ridge fault strands are to the south. This fault geometry defines a crude structural symmetry that is centered roughly about the topographic crest of Mission Ridge.

The El Encanto fault in western Goleta Valley is inferred from a 3.4-km-long northwest-trending geomorphic lineament consisting of aligned linear drainage channels, depressions, and a subdued scarp near its southeast end. The fault is interpreted to have southwest-up, reverse displacement based on slightly higher ground surfaces southwest of the lineament and a northeast-facing apparent fault-line scarp that crosses Hollister Avenue south of U.S. Highway 101. A youthful age for the probable El Encanto fault is suggested by its geomorphic expression in upper Pleistocene deposits (Qia, Omt). To the south in the Isla Vista-U.C. Santa Barbara campus area, the Isla Vista fault is similarly partially expressed by westnorthwest-trending geomorphic and aerial-photographic lineaments formed on upper Pleistocene marine-terrace deposits $(\mathrm{Qmt})$; one consisting of a small linear canyon draining into the east side of Devereaux Lagoon and the other an aligned pond, spring, and depression in Anisqoyo Park in downtown Isla Vista. Additionally, lithologic, structural, and age contrasts exist in upper Miocene and Pliocene rocks of the Sisquoc Formation (Tsq) across the western and eastern ends of the Isla Vista fault trace. Near the western end, mudstone and shale within the Sisquoc is soft to moderately hard and nonporcelaneous in sea cliff exposures north of the fault trace, whereas they are hard, brittle, and porcelaneous at Coal Oil Point south of the trace, suggesting a large contrast in diagenetic grade across the fault. Sisquoc beds dip in opposite directions across the western end of the fault trace, and toward the east end, beds exhibit abrupt dip reversals across the fault where it transects the lagoon north of Goleta Point. Finally, Sisquoc samples from the sea cliffs on either side of the eastern end of the fault trace contrast in biostratigraphic age by several million years (J.A. Barron, USGS, oral and written commun., 2005). Thus, the Isla Vista fault probably experienced a significant amount of probable oblique-slip displacement (several kilometers?) prior to formation of the $\sim 45 \mathrm{ka}$ marine terrace underlying the Isla Vista area. Presumably since 
$\sim 45 \mathrm{ka}$ additional movement has occurred along the western and eastern parts of the fault that has at least mildly disrupted the marine-terrace deposits.

Most of the faults and related folds of the SBFFB deform Quaternary deposits in the coastal lowlands (fig. 11), but the structural belt continues northwest into older Tertiary (Eocene through Miocene) rocks along the south flank of the Santa Ynez Mountains north and northwest of Goleta Valley (fig. 5). Although many of the faults and some of the folds in these Tertiary rocks strike and trend west-northwest subparallel to structures to the southeast on the coastal plain (for example, San Jose, San Pedro, Carneros, and Glen Annie faults), the range of orientations is much greater in the older rocks, with a few faults (for example, Old San Marcos Road fault) and numerous fold axes having north-northwest trends (fig. 11). Most of the north-northwest-trending folds in the mountainous areas north of Goleta Valley are broad, open folds that consistently plunge to the southeast, suggesting that they are incipient folds that became inactive early in their development and were tilted southward together with the surrounding Tertiary strata as the Santa Ynez Mountains were uplifted. Similar northwest-trending folds, but with steeper limbs, closer spacings, and negligible plunges, are present in Miocene and lower Pliocene rocks (Tml, Tmm, Tsq) exposed in the sea cliffs in the La Mesa, Goleta Point, and Ellwood areas.

The SBFFB is superimposed on the regionally extensive south-dipping flank of the Santa Ynez Mountains uplift, which is grossly homoclinal but in detail characterized by overturned strata with steep to moderate dips east of lower San Roque Canyon (north of Santa Barbara) and by upright, moderately south dipping strata west of the canyon. The overturned section continues intermittently along the upper flanks of the Santa Ynez Mountains for more than $50 \mathrm{~km}$ to the east as far as Ojai and has been variously called the Montecito overturn or Matilija overturn (Dickinson, 1969; Dibblee, 1982). In the map area north of Carpinteria, a south-vergent overturned syncline (fig. 11, Arroyo Parida syncline) is exposed along the base of the main Santa Ynez uplift north of the Arroyo Parida fault. Although the upright south limb of this syncline cannot be traced west into the northern Montecito Valley due to burial by upper Pleistocene alluvial deposits (Qia), its overturned north limb is continuous with the overturned section north of Montecito and Santa Barbara. Most likely the axis of the Arroyo Parida syncline intersects and is displaced or disrupted by the similar-trending Mission Ridge fault zone in the Montecito Valley area, because farther west in the Mission Ridge area the fault zone separates the overturned section in its northern footwall block from upright, mostly south-dipping Miocene strata (Tr, Tml, Tmm, Tmu) to the south. Thus a south-vergent syncline likely forms the southern base or edge of the Santa Ynez uplift at shallow depth across the entire eastern map area (east of San Roque Canyon), perhaps reflecting the existence of a large, south-directed thrust or thrust ramp at greater depth that continues well east of the map area (Namson and Davis, 1988). The eastward transition between upright and overturned stratal dips in the San Roque Canyon area is fairly abrupt and appears to be structurally accommodated by a zone of northeast-striking sinistral-oblique faults related to the northeast branch of the More Ranch fault (fig. 11). These faults may have acted as tear faults that accommodated eastward-increasing south-southwest-directed contraction.

\section{Fault Kinematic Constraints}

As part of our geologic mapping efforts to document the structural geology of the coastal plain area, we collected kinematic data (slip-surface orientation and slickenline rake measurements and slip-sense determinations) from 192 smaller-displacement $(<5 \mathrm{~m})$ fault surfaces and 40 largerdisplacement $(5$ to $>100 \mathrm{~m}$ ) fault surfaces exposed in the map area within sedimentary rocks and deposits ranging in age from middle Eocene (Tcw) to late Pleistocene (Qia, Omt) (fig. 12). [Note: Slip-lineation (for example, slickenline) bearing and rake measurements taken at exposures of larger-displacement faults are shown on the cartographic representation of the map, whereas all of the kinematic data (slip-lineation bearing, rake, slip sense, slip-sense certainty) from both largerdisplacement faults and smaller-displacement minor faults are embedded as "point" data in the geologic map database.] Kinematic data, collected along faults in middle Miocene (Tml) and older rocks where the SBFFB continues northwest into the south flank of the Santa Ynez Mountains, reveal a protracted history of faulting in the area leading up to the Quaternary deformation that is best expressed on the coastal plain. West-northwest- to northwest-striking faults cutting rocks as young as the lower Monterey Formation (Tml) in the northwest part of the map area exhibit multiple generations of slickenlines indicating older normal- and oblique normal-slip movement and younger oblique strike-slip movement (fig. 11). Oblique-slip faults in this area commonly can be restored to nearly pure normal-slip or strike-slip faults by back-tilting bedding to horizontal, suggesting that much of the folding and associated reverse faulting in the SBFFB were preceded by normal- and strike-slip faulting. Small oblique-slip faults that similarly restore to strike slip by back-tilting exist in Eocene rocks (Tcw, Tspl) exposed on the ridge north of Carpinteria. Also, numerous small northeast-striking normal faults and extensional fractures filled with calcite veins are present in sea-cliff exposures of upper and middle Miocene Monterey rocks (Tmm) just east of the mouth of Arroyo Burro (Gross and others, 1998). Opposing senses of normal stratigraphic offset on some adjacent mapped faults north and northwest of Goleta Valley suggest that subparallel horsts and grabens once dominated the structural framework of the region, and explain the opposing strike separations of moderately dipping unit contacts across similarly striking faults in the area. In the Miocene and older rocks of this area and in the Mission Ridge fault zone, some individual west-northwest- to northnorthwest-striking fault surfaces show kinematic evidence of both dextral and sinistral strike-slip movement, and in many 
cases cross-cutting relations of slickenlines indicate that dextral slip postdates sinistral slip. In bedrock exposures in the La Mesa sea cliffs (fig. 7) and at some inland exposures, reverse faults contain multiple generations of slickenlines that exhibit progressive shifts in rake, suggesting either progressive counterclockwise rotation of the maximum compression axis or clockwise rotation of the faults. Faults in middle and upper Pleistocene marine and alluvial sediments exposed on the coastal plain (Qsb, Omt, Qoa, Qia) lack evidence of early normal slip, but otherwise have strike-slip histories similar to faults in the older rocks and show abundant evidence of late reverse and oblique reverse movement. As described above, north-northwest-trending folds that are oblique to folds in younger deposits on the coastal plain are restricted to Tertiary rocks in the northwest map area and along the sea cliffs west of Santa Barbara. All of these structural observations are consistent with previous tectonic models constrained by paleomagnetic data that invoke large (up to $\sim 90^{\circ}$ ), Neogene, clockwise vertical-axis rotations of crustal fault blocks in the western Transverse Ranges (Hornafius and others, 1986; Luyendyk, 1991) accompanied by a gradual evolution from transtensional (normal-strike slip) to transpressional (strike slip-reverse) fault kinematics beginning in the middle Miocene (17-15 Ma) (Luyendyk, 1991; Dickinson, 1996). Significant components of strike slip observed on oblique-reverse faults cutting youthful deposits on the coastal plain imply that significant transpressional strain, possibly accompanied by clockwise rotation of crustal fault blocks, continued into the middle to late Pleistocene. Recent results from very long baseline interferometry geodetic observations indicate that crustal blocks within the western Transverse Ranges are actively rotating clockwise (Molnar and Gipson, 1994), consistent with the youthful (late Pleistocene) transpressional deformation observed on the coastal plain.

\section{Timing of Deformation}

The geologic mapping presented in this report does not address any Paleogene or earlier deformation that may have occured in the map area. However, the timing of late Cenozoic deformation in the Santa Barbara coastal plain region is constrained by mapped structural and stratigraphic relations. Stratigraphic evidence of possible early late Neogene tectonic disturbances in the western coastal map area includes locally pronounced late Miocene erosional disconformities at the base of the unnamed mudstone unit (Tu) and the base of the Sisquoc Formation (Tsq); and the presence of large angular (olistostromal?) blocks and boulders derived from the Monterey Formation in upper Miocene and lower Pliocene conglomerates of the Sisquoc Formation (fig. 13). Such disruptions in marine sedimentation may have resulted from tectonically induced uplift and erosion (Hornafius, 1994b) and coeval, seismically triggered(?) submarine slumps and debris flows of coarse detritus. This uplift, erosion, and shedding of debris may have been associated with the early episode of transtensional normal and normal-oblique faulting that is expressed by normal slip indicators and stratigraphic separations on faults in upper Miocene age (Tmm) and older rocks (see preceding section). Alternatively, these events may have signaled the beginning of transpressional folding and faulting, perhaps associated with early uplift of an incipient Santa Ynez mountain block north of the map area (Hornafius, 1994b), or the disconformities may reflect periods of erosion related to eustatic drops in sea level.

The timing of the main episode of uplift of the Santa Ynez Mountains and adjacent uplands in the Santa Barbara area is indicated by several lines of evidence. Along the lower southern flank of the Santa Ynez Mountains, similar concordant moderate to steep southerly and, where overturned, northerly dips are observed in all exposed bedrock units, which are as young as the early and middle Miocene lower subunit of the Monterey Formation (Tml). Also, in coastal exposures, no detectable angular unconformities exist in lower Pliocene Sisquoc Formation (Tsq) and older strata. An erosional angular unconformity that is exposed in the La Mesa and northern Goleta Valley areas separates tilted rocks of the Sisquoc Formation and older units from less-tilted overlying marine deposits of late Pliocene(?) to middle Pleistocene age (Qsb, QTst, Qss, Qcg) with as much as $30^{\circ}$ of dip discordance. This unconformity indicates that significant southward tilting and erosion occurred in the coastal area in the Pliocene and (or) early Pleistocene. All of the above geologic relations are consistent with the initiation of arching and uplift of the Santa Ynez Mountains along an axis just north of the map area during this time interval (Dibblee, 1982). Furthermore, locally derived coarse conglomerates and gravels that are present in the upper part of the Santa Barbara Formation and in the overlying Casitas Formation (Qca) and older alluvial deposits (Qoa) suggest that significant uplift and erosion of the Santa Ynez block continued during the middle and late Pleistocene (fig. 10). Moderate angular discordances between Santa Barbara strata and overlying older alluvial deposits (Qoa) in some parts of northeastern Goleta Valley indicate that fold- and (or) fault-related tilting occurred in the middle(?) Pleistocene on the adjacent coastal plain as Santa Ynez uplift continued.

Numerous large faults and folds clearly deform older alluvial deposits on the coastal plain and have clear geomorphic expression (figs. 8, 9, and 10), implying that strong transpressional deformation continued well into, and perhaps through, the middle Pleistocene. Deformation continued into the late Pleistocene as evidenced by uplifted, warped, and faulted, wave-cut marine platforms and capping marine-terrace (Qmt) and alluvial (Qia) deposits (figs. 8 and 9). Gurrola and others (2001) (see also Keller and Gurrola, 2000) have calculated uplift rates of dated 45- to 105-ka marine terraces that range from $0.7 \mathrm{~m} / \mathrm{ky}$ to $2.2 \mathrm{~m} / \mathrm{ky}$. No significant deformation has been recognized in the mapped Holocene deposits despite historic earthquake activity and geodetic evidence for active tectonic rotation (Molnar and Gipson, 1994) in 
the region. Collectively, the various structural age relations described above imply that late Cenozoic uplift and related transpressional deformation in the coastal plain area was most pronounced during the Pliocene and Pleistocene, and was preceded by a possibly widespread episode of normal faulting and transtensional deformation during the middle to late Miocene.

\section{Cenozoic Geologic History}

Paleogene strata of the western Transverse Ranges accumulated in a regional forearc basin that originally extended from the Great Valley of California to northwestern Mexico (Dickinson, 1995). Sedimentary strata in this forearc marine basin were deposited in a variety of depositional systems that, in general, record gradual shallowing from deep-water environments during Paleocene and early Eocene time to shallow-water and subaerial environments during later Eocene and Oligocene time. In the Santa Barbara coastal plain area, the transition from shallow marine to terrestrial deposition is recorded, respectively, by Coldwater Sandstone (Tcw) and Sespe Formation (Tspl, Tspm, Tspu). The progressive shallowing of the basin has been attributed to (1) gradual filling of the forearc basin with clastic sediment as rates of sedimentation exceeded rates of subsidence, and (2) regional tectonic uplift of the entire California forearc by subduction of younger, buoyant oceanic lithosphere as the Farallon-Pacific spreading ridge approached the continental margin prior to establishment of the modern San Andreas transform system (Nilsen, 1984; Dickinson, 1995). Terrestrial sedimentation during the latter part of this transitional period was interrupted by a regionally extensive hiatus in deposition of the Sespe Formation (between units Tspl and Tspm) that may have lasted for more than 7 m.y. during much or all of the early Oligocene (Howard, 1995). This nondepositional episode may have resulted from regional tectonic uplift associated with the "Ynezian" orogeny that was centered just north of the present Santa Ynez Mountains in the region of the modern Santa Maria basin (Dibblee, 1950, 1966). Alternatively, the intraSespe disconformity may have been created by erosion during a eustatic fall in sea level, although the relative importance of tectonics and eustasy in creating this unconformity is unclear (Howard, 1995).

In the Santa Barbara area, renewed subsidence during the late Oligocene resulted in deposition of the shallow-marine Vaqueros Formation (Tv). Continued subsidence during the Miocene was accompanied by deposition of three fine-grained units - the Rincon Shale (Tr), Monterey Formation (Tml, Tmm, Tmu), and Sisquoc Formation (Tsq) - in a variety of deep-water depositional environments ranging from bank top to slope and basin. The Miocene paleogeography of the Santa Barbara area probably resembled the modern southern California borderland, with alternating paleobathymetric highs and lows that formed a series of banks and intervening basins (Hornafius, 1991). This complicated paleogeography was strongly controlled by middle Miocene to early Pliocene ( $\sim 17$ to $5 \mathrm{Ma}$ ) transrotational tectonism, which was characterized by clockwise rotations of crustal fault blocks that rotated as much as $60^{\circ}$ clockwise about vertical axes (Luyendyk 1991; Dickinson, 1996). Early transtensional clockwise rotation of crustal blocks within the western Transverse Ranges resulted from the establishment in the middle Miocene of a broad, gradually extending, northwest-trending zone of distributed dextral shear that accommodated slightly divergent relative transform motion between the Pacific and North American tectonic plates (Luyendyk 1991; Atwater and Stock, 1998). Near the end of the Miocene, uplifted crustal blocks resulting from the transrotational tectonism may have created large, unstable exposures of the Monterey Formation, which provided sources for the thick horizons of coarse conglomerate observed in the Sisquoc Formation.

The transtensional (normal-sinistral strike-slip) faulting that accommodated clockwise fault block rotations beginning at about $17 \mathrm{Ma}$ was largely replaced by transpressional (reverse-strike slip) faulting and associated folding and uplift during or after upper Monterey (Tmu) deposition, in the late Miocene (after $\sim 10 \mathrm{Ma}$ ) and (or) Pliocene (Luyendyk, 1991). The exact timing and underlying cause(s) of a similar late Neogene change to compressional tectonism observed throughout much of coastal California are broadly debated, but it may have been related to changes in plate motions along the Pacific-North America plate boundary that occurred at $\sim 8$ $\mathrm{Ma}$ (Atwater and Stock, 1998) or possibly as late as $\sim 3.5 \mathrm{Ma}$ (Page and others, 1998). In the western Transverse Ranges, the shift to transpressional deformation is also consistent with tectonic models invoking continued clockwise rotation of crustal fault blocks within a broad plate-boundary zone of bulk dextral shear that began to contract in the late Neogene due to the change(s) in plate motions (Luyendyk, 1991; Dickinson, 1996). Major uplift of the Santa Ynez Mountains likely began early in the transpressional episode during the Pliocene, possibly due to early movement at depth on one or more large south-directed thrust faults (Namson and Davis, 1988). This early uplift was accompanied by moderate folding, southward tilting, reverse-sinistral oblique-slip faulting, and clockwise rotation of resulting structures throughout the coastal plain area.

The sea encroached landward from the south in the early to middle Pleistocene, resulting in shallow marine deposition of sand-rich sediment of the Santa Barbara Formation (Qsb) and the lithologically varied sedimentary rocks east of Goleta Pier (QTst, Qss, Qcg) on a southward-deepening and -thickening, possibly tectonically subsided marine shelf (Jackson and Yeats, 1982) that may have been transected by several submarine canyons. Episodic uplift and erosion of the Santa Ynez Mountains continued during the Pleistocene as recorded by accumulations of locally derived conglomeratic and gravel-rich strata that were deposited in shallow-marine and, eventually, nonmarine coastal piedmont environments. Such coarse-grained strata comprise upper parts of the marine Santa Barbara Formation and unnamed sedimentary rocks 
east of Goleta Pier ( $\mathrm{Ocg}$ ), and they characterize most of the overlying terrestrial Casitas Formation (Qca) and alluvial fan deposits (Qoa, Qia). Numerous unconformities that bound and exist within the Pleistocene deposits record a complex interplay between local tectonism and global changes in sea level. The end of marine sedimentation of the Santa Barbara Formation was marked by a middle to late Pleistocene episode of renewed transpressional faulting, folding, and uplift in the Santa Barbara fold and fault belt. During this episode, both reverse-sinistral and reverse-dextral oblique-slip faulting occurred along similar west-northwest trends on the newly emerged coastal plain, perhaps reflecting: (1) transpressional reactivation of older transtensional structures beneath the Pleistocene cover deposits; and (2) competing influences of continued clockwise transrotation of fault blocks (reversesinistral faulting) and increasing transform-parallel dextral shear resolved onto faults rotated to northwest strikes (reversedextral faulting). Late reverse-sinistral fault displacement occurred on several cross-cutting structures along northeast trends (for example, More Ranch fault system) orientations that may have become more favorable for accommodating further clockwise rotation than the older, previously rotated, west-northwest fault trends accomodating dextral shear.

Beginning at about $105 \mathrm{ka}$, and possibly much earlier, terrace basal abrasion surfaces were cut by wave action along the coast during multiple interglacial sea-level high stands, with accumulation of overlying marine-terrace $(\mathrm{Qmt})$ and alluvial (Qoa and Qia) deposits during subsequent marine regressions resulting from eustatic drops in sea level and tectonic uplift (Rockwell and others, 1992; Muhs and others, 1992; Keller and Gurrola, 2000; Gurrola and others, 2001). Marine-terrace surfaces spanning segments of the coastline were differentially uplifted into broad upwarps, some of which were coincident with pre-existing folds formed in underlying deposits. Late movement along some faults, including the central and western segments of the More Ranch fault system, resulted in locally pronounced folding and reverse-oblique displacement of marine-terrace deposits. Alluvial and colluvial deposition ( $\mathrm{Qa}$, Qac, and Qc) continued into the Holocene on broad low-lying, possibly downwarped (Keller and Gurrola,
2000; Gurrola and others, 2001) floodplains underlying Goleta Valley, downtown Santa Barbara, Montecito, the Carpinteria area, and elsewhere along major stream canyons. This sedimentation was locally accompanied by the deposition of estuarine deposits $(\mathrm{Qe})$ in low-lying coastal areas owing to local subsidence and (or) possible sea-level rise. During times of heavy precipitation in the late Pleistocene and Holocene, relatively steeply sloping areas in the map area underlain by clay-rich sedimentary rocks were, and continue to be, prone to landsliding and (or) debris flows. Deposits resulting from such slope failures (units Qls and Qdf) include the large Mission debris flow, which was deposited on a now-urbanized part of the coastal plain in the central part of the map area (Selting and Urban, in Gurrola and others, 2001; Urban, 2004).

\section{Acknowledgments}

The present mapping effort was funded by the USGS National Cooperative Geologic Mapping Program's Southern California Areal Mapping Project (SCAMP). The unwavering support of SCAMP chief Doug Morton allowed our coastalplain mapping efforts to continue smoothly to their completion. We are grateful to Paul Stone for his significant mapping contributions to the preliminary version of this compilation and for his critical support throughout the mapping campaign. Chuck Powell and John Barron made important paleontologic and biostratigraphic contributions to our mapping efforts. We thank Jim Messerich of the USGS Laboratory for Geologic Photogrammetry and Digital Mapping, Denver, Colo., for his professional photogrammetric support. Constructive reviews by Art Sylvester of an earlier draft of this map and by Paul Stone, Jim Cole, and Jeremy Workman of the final draft improved the quality of the map, map text, and map database. Finally, the late Tom Dibblee is due special acknowledgment for his numerous pioneering and far-reaching contributions to our understanding of the geology of the Santa Barbara region and of southern California in general. His earlier geologic mapping in the Santa Barbara coastal plain region formed an invaluable foundation for our new mapping efforts. 


\section{DESCRIPTION OF MAP UNITS}

af Artificial fill (Holocene) - Mappable areas of fill used for construction of highways, roads, buildings, airport runways, harbor facilities, breakwaters, and dams

$\mathrm{Qa}$

Active channel alluvium (Holocene)—Unconsolidated sediments, primarily pebble to boulder gravel, in floors and banks of modern stream channels. Commonly incised as much as $5 \mathrm{~m}$ into alluvial deposits of associated floodplain (Qac). Thickness less than $5 \mathrm{~m}$

$\mathrm{Qb}$

Beach deposits (Holocene) - Unconsolidated marine-shoreline beach sediment, mostly fine-to medium-grained, well-sorted, clean, light-grayish-tan sand composed predominantly of quartz, feldspar, and lithic grains. Includes subordinate shell fragments, plant remains, and human litter. Thickness of deposits probably rarely exceeds $5 \mathrm{~m}$ and varies seasonally mainly due to storm-surge beach erosion; occasionally during the winter months sand is completely stripped away in places, exposing the underlying bedrock

Ods Dune sand (Holocene) - Unconsolidated wind-blown sand forming hummocky dunes. Forms small coastal dune field bordering south end of Devereaux Lagoon just northwest of Coal Oil Point

Qe Estuarine deposits (Holocene)—Dark-brown and dark-gray clay, silt, and subordinate sand deposited primarily in brackish-water, peritidal environment; locally rich in decomposed terrestrial organic matter, including peat. Unit consists mostly of lenticular channel and interchannel deposits; sediments are locally laminated or bioturbated. Estuarine deposits form areas of flat, low-lying topography that are largely covered by marshy vegetation or urban development and were mapped primarily by means of aerial photographs and digital elevation models. Estuarine deposits underlie coastal areas including Devereaux Lagoon and Goleta Slough, lower downtown Santa Barbara, Andre Clark Bird Refuge, and El Estero near Carpinteria. Maximum thickness of deposits unknown, but probably less than $20 \mathrm{~m}$

Qas Asphalt deposits (Holocene)—Black, tar-like asphalt that represents weathered and biodegraded oil derived from nearby natural seeps. Moderately hard to very hard and brittle; freshly broken pieces emit a strong petroliferous odor. Primarily form low mounds 1-10 $\mathrm{m}$ across and 1-3 $\mathrm{m}$ thick and drape-like accumulations on the sea cliff 1-5 $\mathrm{m}$ across and 1-5 m high; such deposits are depicted on map by point symbols. Also form sheets of undetermined thickness that extend laterally for tens of meters. Locally contain shells, angular fragments of older asphalt, and rock fragments. Commonly overlie beach sand and older landslide deposits derived from erosion of the modern sea cliff; commonly overlain by recent beach sand and landslide deposits. Exposed surfaces of some accumulations are overgrown by intertidal organisms and terrestrial vegetation. Typically spatially associated with asphalt-filled fractures in Pleistocene sandstone unit (Qss) and Pleistocene and Pliocene siltstone unit (QTst)

Qdf Debris-flow deposits (Holocene and upper Pleistocene?)—Massive, weakly consolidated, coarse-grained, poorly sorted, generally matrix-supported rock-debris breccia. Mainly located along lower flanks of Santa Ynez Mountains in northern map area and composed of sandstone and mudstone debris derived from Coldwater Sandstone (Tcw) and Sespe Formation (Tspu, Tspm, Tspl) exposed upslope.

The Mission debris-flow deposit (Selting and Urban, in Gurrola and others, 2001; Urban, 2004), near confluence of Mission and Rattlesnake Canyons in Santa Barbara, contains abundant boulders as large as $5 \mathrm{~m}$ in diameter and exhibits a large range in grain size (boulder to clay); clasts mostly consist of tan to gray sandstone derived from Coldwater Sandstone (Tcw) and older Eocene units. Most boulders in the Mission deposit are subangular to subrounded and lack weathering rinds or oxidation staining. Majority of deposit is ungraded but examples of crude normal and reverse grading are observed locally. Deposit can be traced up floor of Rattlesnake Canyon to inferred source of debris flow in large landslide deposit (Ols) at Skofield Park. Deposit has an estimated average thickness of $8.7 \mathrm{~m}$ and an estimated volume of $9.2 \times 10^{6} \mathrm{~m}^{3}$ (Urban, 2004). Age is inferred to be less than 1,000 years largely based on two ${ }^{14} \mathrm{C}$ dates on charcoal $(1,460 \pm 40$ and $1,000 \pm 40 \mathrm{yr}$ B.P., J.P. McGeehin, USGS, written commun., 2003) (Urban, 2004). 
Youthful, lobate geomorphic expression of most deposits suggests they are Holocene in age, but considerable erosional dissection of a few deposits suggest some debris flows were emplaced during the late Pleistocene. Most deposits estimated to be less than $5 \mathrm{~m}$ thick

Qac

Qc
Alluvium and colluvium (Holocene and upper Pleistocene)-Unconsolidated to weakly consolidated silt, sand, and gravel deposits of modern drainages and piedmont alluvial fans and floodplains. Deposits inferred to underlie much of the Goleta, Santa Barbara, Montecito, and Carpinteria urbanized areas and many of the larger broad canyon floors in the western half of the map area. Where exposed, alluvium is composed of poorly to moderately sorted silt, sand, and pebble to boulder gravel that commonly occupy paleochannels. Flanking colluvial deposits are composed primarily of poorly sorted, angular clasts, with longest axis as great as $1 \mathrm{~m}$, in a fine-grained matrix. Geomorphic surfaces underlain by alluvium and colluvium commonly contain poorly to moderately developed soil profiles and exhibit weak to moderate erosional dissection. Exposed thickness of alluvial and colluvial deposits generally less than $10 \mathrm{~m}$

Colluvium (Holocene and upper Pleistocene)—Unconsolidated to weakly indurated, mostly non-stratified, dark-brown to light-gray-brown deposits that mantle gentle to moderate slopes. Consists of angular to subrounded pebbles, cobbles, and boulders mixed with finegrained material, mostly derived from weathering and downslope movement of nearby bedrock. Includes sheetwash deposits and some small landslide deposits on slopes, minor alluvium in small channels, and deposits of wind-blown sand, silt, and minor clay in areas of open gentle slopes. Colluvial deposits commonly capped by poorly to moderately developed soil profiles. Smaller colluvial deposits are not mapped, particularly where thin and discontinuous. Maximum thickness of colluvial deposits probably less than $15 \mathrm{~m}$

Landslide deposits (Holocene to middle Pleistocene)—Deposits of diverse slope-movement processes including earth slides, earth flows, rock slides, debris slides, and rock slumps (Bezore and Wills, 2000; terminology of Cruden and Varnes, 1996). Deposits range from poorly sorted, disrupted mixtures of rock fragments and soil to relatively intact bedrock slump blocks. Surfaces of deposits commonly hummocky; relatively steep breakaway zones identifiable in places. Rincon Shale (Tr), middle shale unit of Monterey Formation (Tmm), and relatively fine grained intervals in the Sespe Formation (Tspu, Tspm, Tspl) and Coldwater Sandstone (Tcw) are particularly susceptible to sliding (mostly by earth flow), although slides have occurred in most units where oversteepening of slopes has promoted slip. Largest landslide deposits may be as thick as $60 \mathrm{~m}$

Travertine and caliche(?) deposits (Holocene? and Pleistocene?) —White, massive, lowdensity, locally vuggy deposits of very fine-grained, micritic calcium carbonate. Contains embedded pebbles as long as $\sim 5 \mathrm{~cm}$. Small deposits are located at three sites in central part of map area and are depicted by point symbols. At one locality just north of Cathedral Oaks Road, $0.5 \mathrm{~km}$ northeast of intersection with Los Carneros Road, carbonate forms layers as thick as $\sim 10 \mathrm{~cm}$ within soil that also comprises numerous float blocks scattered on hillside. This deposit may be either travertine precipitated from an ancient fault-related(?) carbonate-rich spring or pedogenic caliche. Just west of Fairview Avenue, $0.5 \mathrm{~km}$ north of Cathedral Oaks Road, travertine forms globular masses as thick as $0.5 \mathrm{~m}$ that probably resulted from now-inactive spring activity. Small resistant outcrop about $1.4 \mathrm{~km}$ northwest of Santa Barbara Mission just north of Foothill Road consists of white chalky, flaggy micritic carbonate that may have precipitated along fault that thrusts lower calcareous unit of the Monterey Formation ( $\mathrm{Tml}$ ) over older alluvial deposits (Ooa)

Intermediate alluvial deposits (upper Pleistocene) - Orange-brown to tan, weakly consolidated, stratified silt, sand, and pebble, cobble, and rare boulder gravel. Well-rounded clasts, rarely longer than $10 \mathrm{~cm}$, include Eocene marine sandstone, sandstone from the Sespe Formation, and rare reworked, rounded cobbles and pebbles derived from conglomerates of the Sespe Formation. Forms low, rounded, moderately dissected terraces that, in the Goleta area, are as high as $\sim 15 \mathrm{~m}$ above the modern coastal piedmont surface. Average clast size decreases to south, away from sources in the Santa Ynez Mountains.

Extensive, possible intermediate-age, alluvial deposits in the Montecito area (mapped as Qia?) and intermediate alluvial deposits north of Carpinteria were primarily deposited 
as piedmont alluvial fans. North and west of Goleta, where northern edge of unit approximately coincides with a possible older, elevated shoreline angle (that is, the landward edge of a marine abrasion platform), the unit may include older marine-terrace deposits ( $\mathrm{Omt}$ ). Farther west, intermediate alluvial deposits grade laterally into a coastal strip of marineterrace deposits $(\mathrm{Omt})$ such that mapped contact separating two units between Glen Annie Road and Bell Canyon is mostly arbitrary and is very approximately located. Intermediate alluvial deposits are topographically lower and, thus, younger than adjacent older alluvial deposits (Qoa), and generally contain smaller clasts. However, in some areas, deposits mapped as intermediate in age may be temporally equivalent to deposits mapped as older alluvial deposits (Coa) in other areas.

Late Pleistocene age of unit mainly based on lateral correlation with relatively welldated marine-terrace deposits $(\mathrm{Qmt})$ and late Pleistocene age of underlying older alluvial deposits (Qoa).

Unit was previously mapped as fanglomerate, older alluvium, and alluvium (Dibblee, 1966) and older dissected surficial sediments (Dibblee, 1986a, 1986b, 1987a, 1987b). Base of unit not exposed; thickness probably locally greater than $20 \mathrm{~m}$.

Qmt

Marine-terrace deposits (upper Pleistocene)-Mostly pale- to medium-tan, -brown, and -gray, weakly to moderately consolidated, crudely to moderately bedded, pebble-cobble gravel and conglomerate, pebbly to conglomeratic sand and sandstone, and silt and siltstone. Deposits unconformably overlie eroded bedrock or older sediments on elevated marine wave-cut abrasion platforms. Lower part of marine-terrace sequences typically consists of a thin $(\leq 1 \mathrm{~m}$-thick) basal layer of fossiliferous cobble to pebble gravel or conglomerate that locally grades upward into laminated to massive beach(?) sand or sandstone and (or) estuarine organic-rich clay and silt. Basal gravel and conglomerate clasts commonly exhibit mollusk (pholad) borings that rarely contain pholad shells. An open-coast invertebrate fauna of at least 125 taxa, including 102 mollusks and 18 foraminifers, has been collected from the lowermost emergent terrace of this unit near Goleta (Wright, 1972; C.L. Powell II, USGS, unpub. data, 2001). The mollusks from this terrace inhabited an exposed rocky and sandy shore from intertidal to inner sublittoral depths (0-9 m) (Valentine, 1961; Wright, 1972). Among the fauna is the rare fossil solitary coral Balanophyllia elegans (Verrill) (Gurrola and others, 2001). Upper two-thirds or more of terrace sequences typically includes nonmarine eolian sand or sandstone and silt or siltstone, stratified fluvial and alluvial pebble-cobble gravel or conglomerate, and minor colluvial deposits.

Marine-terrace deposits are well exposed in upper parts of sea cliffs that span the western two-thirds of map area nearly continuously and are intermittently preserved in the eastern third. Marine-terrace deposits probably underlie the elevated, locally dissected coastal mesas that extend inland from the sea cliffs and, in western Goleta Valley, may extend beneath the broad area of moderately dissected intermediate alluvial deposits (Qia). Positive correlation of a small, poorly exposed deposit north of Lake Los Carneros in Goleta Valley (labeled Qmt?) with the marine-terrace unit awaits age determination of marine fossils that are contained within it. Flights of marine terraces and underlying marine-terrace deposits are locally preserved along the coast and are bounded along their back edges by shoreline angles that mark bases of adjacent terrace-riser scarps (erosionally modified paleo-sea cliffs?). In the Hope Ranch area on either side of southern Las Palmas Drive and in the La Mesa area, as many as four terrace surfaces, formed on four distinct levels of marine-terrace deposits, are preserved ranging in elevation from about $30 \mathrm{~m}$ to as

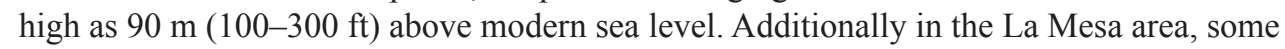
terrace deposits and beveled bedrock surfaces have elevations as great as $120 \mathrm{~m}(400 \mathrm{ft})$, but it is uncertain if these deposits (mapped as $\mathrm{Omt}$ ?) and surfaces are of marine origin. Elevation of lowest emergent marine terrace in Isla Vista area is about $10 \mathrm{~m}(30-40 \mathrm{ft})$.

Marine-terrace basal-abrasion surfaces in map area probably formed during interglacial sea-level high stands, whereas the overlying terrace deposits most likely accumulated during marine regressions resulting from eustatic drops in sea level and (or) tectonic uplift (Rockwell and others, 1992; Muhs and others, 1992; Keller and Gurrola, 2000; Gurrola and others, 2001). First emergent marine terraces in Ellwood (25 m [60-80 ft] approximate elevation), Isla Vista (10 m [30-40 ft]), and More Mesa (30 m [60-100 ft]) areas are dated 
at approximately $45 \mathrm{ka}$ and are correlated to oxygen isotope substage 3a sea-level high stand, based on integrated results from uranium-series analysis of marine terrace corals, ${ }^{14} \mathrm{C}$ ages of terrace shells and detrital charcoal, optically stimulated luminescence (OSL) of terrace sands, and oxygen isotopic signatures of terrace mollusks (Keller and Gurrola, 2000; Gurrola and others, 2001). The single emergent marine terrace mapped just southeast of Carpinteria (15 m [40-60 ft] elevation) is continuous with the Punta Gorda terrace preserved east of the map area (Tan and Clahan, 2004), which has an estimated age of 45 ka-stage 3 (Kennedy and others, 1982). The first emergent terrace at Santa Barbara Point in the La Mesa area (15 m [50 ft] elevation) has an estimated age of $58 \mathrm{ka}$ based on an OSL measurement and oxygen isotopic signatures of fossil mollusks that correlate with oxygen isotope substage 3c (Keller and Gurrola, 2000). Flights of higher marine terraces preserved in the La Mesa (15-75 m [50-250 ft] elevation range) and Hope Ranch (30-90 m [100-300 $\mathrm{ft}])$ areas, and emergent marine terraces present in the Santa Barbara Cemetery $(20 \mathrm{~m}[70 \mathrm{ft}]$ approximate elevation), Summerland (30 m [100 ft]), and Loon Point (30 m [100 ft]) areas range in age from $70 \mathrm{ka}$ to $105 \mathrm{ka}$ and correlate to oxygen isotope substages $5 \mathrm{a}$ and $5 \mathrm{c}$ sealevel high stands (Gurrola and others, 2001). Keller and Gurrola (2000) infer that the marine terraces forming the narrow, dissected coastal bench west of Bell Canyon (west part of the map area) (20-45 m [70-140 ft] elevation range) also correlate with oxygen isotope stage 5, and they infer that these older terraces extend eastward into northwest Goleta Valley in areas mapped herein as intermediate alluvial deposits (Qia). Dibblee (1966) reported the presence of a jaw bone of a late Pleistocene mammoth (Archidiscodon imperator) in alluvium within marine terrace deposits near the western edge of the map area.

Alluvial deposits typically present in upper part of marine terrace sequences probably correlate with intermediate (Qia) and older (Qoa) alluvial deposits. Marine terrace deposits of this report were previously mapped as terrace deposits (Upson, 1951; Lian, 1954), Carpinteria Formation (Lian, 1954), older alluvium (Dibblee, 1966), and older dissected surficial sediments (Dibblee, 1986a, 1986b, 1987a, 1987b). Maximum exposed thickness about $20 \mathrm{~m}$.

Qoa Older alluvial deposits (upper and middle Pleistocene)—Nonmarine brown, pale-gray, pale-tan, and reddish-brown, moderately consolidated, crudely stratified, poorly sorted, clayey to silty and pebbly sand and sandstone, silty to sandy pebble-cobble-boulder gravel, conglomerate, and breccia, and rare interbeds and partings of sandy to pebbly clay, silt, and mudstone. Sand and sandstone are locally cross laminated. Gravel and conglomerate typically occupy paleochannels or form lenticular beds, and contain subrounded clasts composed primarily of sandstone derived from Eocene formations exposed in Santa Ynez Mountains. Clasts commonly are imbricated. Southwest of La Cumbre Junior High School, lowermost beds contain clasts of siliceous shale and chert possibly derived from Monterey Formation. Breccia composed of subangular clasts mainly of Eocene sandstone typically forms thick ( $>3 \mathrm{~m})$, sheet-like, clast-supported beds probably deposited as debris flows. Most older alluvial deposits are poorly to moderately consolidated, but locally in Mission Ridge area are indurated and cemented (silica?) near basal contact with rocks of the Monterey Formation.

Along front of Santa Ynez Mountains, unit typically forms dissected, gently southsloping terraces and interfluvial caps, as much as $100 \mathrm{~m}$ above modern stream level, interpreted as erosional remnants of old alluvial fans. Clast size generally decreases and sorting increases away from mountain front; coarse breccia deposits, restricted to northern, proximal parts of fan remnants along mountain flanks, include blocks several meters in length. Finer-grained, medial and distal facies commonly erode into badlands topography. On coastal plain, unit is deformed and uplifted by youthful upwarps, folds, and faults and forms rounded hills and ridges, including Mission Ridge in northern Santa Barbara and lower hills in northern Goleta Valley, Montecito, and near Summerland. Some low-lying areas of urban development, including much of downtown Santa Barbara, are inferred to be underlain by Qoa on the basis of geomorphology; such areas are slightly higher in elevation and exhibit greater erosional dissection than adjacent areas of presumably younger deposits (Qac, Qe, Qia) and were mapped primarily by means of aerial photographs and 
digital elevation models. Existence of older alluvial deposits on small ridge crests southwest of Laguna Blanca (areas labeled Qoa?) is uncertain due to lack of exposures.

In most places, the unit overlies Tertiary bedrock units with marked angular discordance. At several localities near El Sueno and south of La Cumbre Junior High School and Harding School in central part of map area, older-most alluvial deposits of unit are interstratified with and conformably overlie sandstone of upper Santa Barbara Formation (Qsb). These deposits closely resemble, and may be correlative with, sediments of the Casitas Formation (Oca) mapped in eastern part of map area. More commonly, however, older alluvial deposits unconformably overlie rocks of the Santa Barbara Formation with as much as $30^{\circ}$ of angular discordance. Most older alluvial deposits of this report were previously mapped as older alluvium (Upson, 1951), dissected and faulted fanglomerate (Lian, 1954), alluvium (Lian, 1954), fanglomerate (Dibblee, 1966), and older dissected surficial sediments (Dibblee, 1986a, 1986b, 1987a, 1987b). Coarser-grained intervals within the older alluvial deposits yield significant quantities of ground water in wells and the unit forms one of the principal aquifer units beneath parts of the coastal plain (Upson, 1951; Muir, 1968).

Unit age is constrained by middle and lower Pleistocene Santa Barbara Formation (Qsb) that underlies and locally interfingers with lower older alluvial deposits, and by elevated, upper Pleistocene marine-terrace deposits $(\mathrm{Omt})$ into which distal facies of older alluvial deposits appear to grade. Maximum exposed thickness is approximately $35 \mathrm{~m}$, but thickness probably is much greater in subsurface under coastal plain

Casitas Formation (upper and middle Pleistocene) - Nonmarine siltstone and silt, sandstone and sand, and conglomerate and gravel forming narrow to wide and thin to thick lenticular interbeds; mostly moderately consolidated to well consolidated. Deposits in aggregate exhibit pale to medium shades of buff, tan, gray, brown, and, locally, red and orange, and they commonly form badlands topography where exposed in cliffs.

Siltstone and silt are commonly pale gray and pale greenish-gray, sandy to clayey, and thinly bedded and laminated. Sandstone and sand are typically buff, pale tan, gray, and greenish-gray, fine to coarse grained, silty and clayey to pebbly, and well bedded and laminated. Sandstone locally contains conglomeratic lenses. In exposures at Ortega Hill, sandstone beds are locally impregnated with oil.

Conglomerate and gravel contain subrounded to rounded pebbles, cobbles, and boulders, combined in various proportions, in a clayey, silty and (or) sandy matrix; deposits are both clast-supported and matrix-supported. Conglomerate and gravel deposits are massive to moderately well stratified, in places appear to fill paleochannels, and form beds that locally exceed $3 \mathrm{~m}$ in thickness. Clasts consist chiefly of locally derived(?) Eocene and Oligocene sandstone and lesser shale and mudstone (Tcw?, Tspl?, Tspm?, Tspu?); subordinate well-rounded pebbles and cobbles of various other lithologies are probably reworked from conglomerates of the middle and lower units of the Sespe Formation (Tspm?, Tspl?).

Casitas Formation was first defined and mapped by Upson (1951). Unit was subsequently mapped in the coastal plain area as Casitas Formation by Lian (1954) and Dibblee $(1966,1986 a)$.

Deposits of the Casitas Formation are mapped only in the eastern, coastal part of the map area where they are mostly exposed in small anticlinal hills cut by sea cliffs (for example, near Santa Barbara Cemetery, at Ortega Hill, and near Loon Point). Casitas deposits are also present in the low hills north of Carpinteria and possibly in a small cut along San Ysidro Creek in Montecito (mapped as Qca?). Casitas deposits closely resemble (and probably are temporally equivalent with) some of the older alluvial deposits (Qoa), particularly where the alluvial deposits immediately overlie sediments of the Santa Barbara Formation (Qsb) in the central part of the map area. The two units can be distinguished, however, by the generally greater amount of clay and silt in Casitas deposits, which results in their somewhat greater consolidation and competency. Also, Casitas deposits contain a greater percentage of Sespe sandstone and reworked conglomerate clasts, exhibit a greater variety of colors, and in some places are more strongly tilted than directly overlying older alluvial deposits. Age of the Casitas Formation in the map area is bracketed by underlying and possibly interfingering middle Pleistocene upper Santa Barbara Formation (Qsb), and 
by emergent upper Pleistocene marine terrace deposits ( $\mathrm{Qmt}$ ) that unconformably overlie it. Maximum exposed thickness does not exceed $50 \mathrm{~m}$, but unit is much thicker just east of the map area near its type section along lower Rincon Creek and in the subsurface of Carpinteria, Montecito, and possibly Santa Barbara (Upson, 1951; Dibblee, 1966; Olson, 1982; Jackson and Yeats, 1982). Coarser-grained intervals within the Casitas yield significant quantities of ground water in wells and the formation forms one of the principal aquifer units beneath the coastal plain east of Santa Barbara (Upson, 1951; Muir, 1968)

Qbx

Qsb

Shale-clast sedimentary breccia (middle Pleistocene) - Nonmarine breccia and conglomerate composed dominantly of clasts of white, beige, and pale-gray shale and mudstone derived from the Monterey Formation. Clasts are matrix- and clast-supported, angular to subangular, and as much as $20 \mathrm{~cm}$ long. Deposits are crudely to moderately stratified. Breccia exposed only on eastern Mission Ridge at base of older alluvial deposits (Ooa) where it directly overlies rocks of the Monterey Formation. Breccia is inferred to be locally derived paleo colluvium. Unit thickness locally exceeds $10 \mathrm{~m}$.

Santa Barbara Formation (middle and lower Pleistocene)-Marine, mostly pale-gray and cream-colored (fresh) to buff, pale-tan, and pale-yellow (weathered), friable, fine- to medium-grained sandstone and pebbly sandstone. Sandstone ranges from bioturbated and massive to crudely or moderately tabular-bedded and planar- to cross-laminated. Locally, pale-gray sandstone is weakly to strongly cemented with carbonate and forms "curb-andgutter" concretions subparallel to bedding. Pebble- and rare cobble-bearing conglomeratic sandstone lenses and intervals contain generally well-rounded polymict clasts that include siliceous shale possibly derived from Monterey Formation (Tmu, Tmm), sandstone possibly derived from Eocene formations exposed in Santa Ynez Mountains (including Tspl, Tcw), and intermediate-to-silicic volcanic rocks possibly reworked from conglomerates of the Sespe Formation (Tspm, Tspl). Conglomeratic layers become more common upsection in exposures near El Sueno and south of La Cumbre Junior High School and Harding School in central part of map area. Partings, interbeds, and thin-bedded intervals of gray and pale-greenish-gray, laminated shale, siltstone, and silty to clayey fine-grained sandstone are subordinate; these commonly contain layers rich in shell hash and locally are stained with rusty-orange iron oxide. Diverse marine invertebrate assemblages of mollusks, bryozoans, and foraminifers are concentrated in multiple stratigraphic intervals, ranging in thickness from less than $1 \mathrm{~m}$ to several tens of meters, distributed throughout all but the uppermost, conglomeratic parts of unit. Typically, shells are disarticulated, fragmented, and concentrated in planar beds and lenses in both sandstone and finer-grained intervals. Unit includes sparse, whitish beds of calcareous coquina, 0.5 to about $3 \mathrm{~m}$ thick and composed almost entirely of shell and (or) bryozoan fragments, and thin layers rich in carbonaceous (fossil plant?) fragments.

Unit typically is poorly exposed and forms subdued rounded hills except in a few locations where it is strongly cemented and forms resistant outcrops and cliffs; silt- and clay-rich intervals locally erode into badlands topography. Maximum exposed thickness is approximately $300 \mathrm{~m}$. Type section of formation is west of Santa Barbara City College, just east of "Airway Beacon" on hill 406 (Dibblee, 1966, 1986b). This section, which exposes a fossiliferous stratigraphic interval about $40 \mathrm{~m}$ thick, is fairly representative of finer-grained, thinly bedded intervals of Santa Barbara Formation, but not of the friable, massive to crudely stratified sandstone that characterizes most of unit in map area.

An isolated eastern sea-cliff exposure of probable Santa Barbara Formation (mapped as Qsb?) exists in the footwall block of the Loon Point fault east of Summerland, consisting of marine(?) pale greenish-gray, laminated to massive and bioturbated, interbedded siltstone, sandstone, and conglomeratic sandstone. Nonmarine sediments of the Casitas Formation (Oca) are thrust over the Santa Barbara(?) deposits in the fault exposure, implying that the exposed marine interval is younger than the structurally overlying Casitas. The upthrusted Casitas deposits, and similar deposits that presumably underlie the marine rocks in the Loon Point footwall block, may reflect local marine regression and concomitant terrestrial deposition followed by a brief marine transgression and return to Santa Barbara deposition. 
A slight to moderate angular unconformity separates Santa Barbara Formation from underlying Miocene and older units (Tspu, Tv, Tr, and Tml) along the northern edge of a west-northwest-trending belt of discontinuous exposures extending from Santa Barbara Harbor to foothills northwest of Goleta. Surface trace of this unconformity marks northern limit of exposures of unit in central map area, but presence of shelf molluscan fossils and lack of shoreface fossils in northern exposures of formation (C.L. Powell II, written commun., 2001) suggests that the original depositional basin extended an unknown distance farther north (compare with Dibblee, 1966). In La Mesa area west of Lavigia Hill, formation is inferred to lap onto an erosional unconformity underlain by more steeply tilted strata (dips $20^{\circ}$ and greater) of Rincon Shale (Tr) and Monterey Formation (Tml). Upper contact of Santa Barbara Formation with younger sedimentary units is generally unconformable and discordant, but Santa Barbara is locally gradational or interstratified with lower conglomerates and gravels of the older alluvial deposits unit (Ooa) and possibly correlative Casitas Formation (Qca). Fossil-barren, cross-laminated sand deposits that underlie marine-terrace deposits ( $\mathrm{Omt}$ ) at the mouth of La Honda Valley (near Santa Barbara City College) are questionably assigned to the Santa Barbara Formation (mapped as Qsb?).

Molluscan fossils from Santa Barbara Formation examined by C.L. Powell II (written commun., 2001), characteristically include bivalves Chlamys spp., Cyclocardia occidentalis (Conrad), C. californica (Dall), Humilaria perlaminosa (Conrad), Lucinoma annulatum (Reeve), Patinopecten caurinus (Gould), Pecten bellus (Conrad), and gastropods Amphissa reticulata (Dall), Boreotrophon spp., Crepidula princeps (Conrad), Olivella biplicata (Sowerby), Neptunea tabulata (Baird), and Turritella cooperi Carpenter. The molluscan fauna are consistent with deposition at shelf water depths and a possible late Pliocene to middle Pleistocene age (C.L. Powell II, written commun., 2001). In addition, a few mollusks known to be no younger than Pliocene, including bivalves Dendostrea? vespertina (Conrad) and Patinopecten healeyi (Arnold) and gastropod Nassarius grammatus (Dall), have been reported from the Santa Barbara Formation (Addicott, 1965; Natural History Museum of Los Angeles County collections), but these findings have not been independently confirmed. Previously, Dibblee (1966) presented a list of molluscan fossils from the formation interpreted to indicate a "late Pliocene(?) to early Pleistocene" age.

Middle and early Pleistocene age provisionally assigned to Santa Barbara Formation in this report is based partly on reconnaissance paleomagnetic data from the coastal plain area. These data suggest that much of the formation was deposited during the normal polarity epoch following the Brunhes-Matuyama geomagnetic reversal at about $780 \mathrm{ka}$ (Keller and Gurrola, 2000; Gurrola and others, 2001; J.W. Hillhouse, USGS, written commun., 2007). However, in at least one exposure in northwestern Goleta Valley (north of Lake Los Carneros) fossil-barren, possible Santa Barbara sandstone (mapped as Qsb?) has reverse polarity suggesting that it was deposited during the preceding Matuyama $(2.60-0.780 \mathrm{Ma})$ interval (J.W. Hillhouse, written commun., 2007). Middle and early Pleistocene age also is consistent with (1) a reported amino-acid racemization age of 500-600 ka for the formation near former Santa Barbara Hospital site (Wehmiller, 1992); (2) strontium-isotope data suggesting an age of 400-900 ka for formation near Santa Barbara Harbor (Patterson and others, 1990); (3) a shift from predominantly dextral to sinistral coiling in planktic foraminifer Neogloboquadrina pachyderma, indicating an age of about $600 \mathrm{ka}$, within formation near Santa Barbara Harbor (Patterson and others, 1990); and (4) a 1.2-Ma age determination for the Bailey ash (Izett, Naeser, and Obradovich, 1974), which directly underlies the Santa Barbara Formation in the Ventura area about $20 \mathrm{~km}$ east of map area (Yerkes, Sarna-Wojcicki, and Lajoie, 1987).

Unit was previously mapped as Santa Barbara Formation by Upson (1951) and Dibblee (1966, 1986b, 1987b). Coarser-grained intervals within the unit yield significant quantities of ground water in wells and the Santa Barbara Formation forms one of the principal aquifer units beneath the coastal plain (Upson, 1951; Muir, 1968)

Unnamed sedimentary rocks east of Goleta Pier (Pleistocene and Pliocene?)—Marine conglomerate, sandstone, siltstone, and mudstone exposed along coast 1.5 to $3.5 \mathrm{~km}$ east of Goleta Pier, previously mapped as unnamed upper Pliocene formation (Upson, 1951), Pico 
Formation (Dibblee, 1966), and Santa Barbara Formation (Dibblee, 1987b). In this study, mapped as three unnamed, lithologically distinct units:

Qcg Conglomeratic unit (middle and lower Pleistocene)—Conglomerate, sandstone, siltstone, and mudstone probably deposited within ancient submarine canyon. Conglomerate is mostly clast supported and consists of angular to rounded granules, pebbles, cobbles, and boulders in a poorly sorted, friable to hard (calcareous), sandy and silty matrix. Clasts larger than $20 \mathrm{~cm}$ commonly are oriented parallel to bedding. Conglomerate beds typically are lenticular and range in thickness from a few centimeters to about $5 \mathrm{~m}$. Some conglomerate beds exhibit inverse-to-normal grading; others exhibit complex, lenticular internal stratification marked by variations in clast size. Bases of most conglomerate beds are sharp, irregular, and erosional. Weak clast imbrication in two beds suggests paleoflow generally to west, southwest, and south. Clasts in lower parts of unit are mainly mudstone, shale, porcelanite, dolomite, and subordinate black phosphorite inferred to be derived from Sisquoc and Monterey Formations; clasts higher in unit additionally include abundant fine- to coarse-grained sandstone possibly derived from Paleogene strata in the Santa Ynez Mountains. Benthic foraminifers and calcareous nannofossils from one dark-brown mudstone clast indicate derivation from middle or lower parts of the Monterey Formation (Tmm or Tml) (R.S. Boettcher and S.A. Kling, Micropaleo Consultants, written commun., 2001). Largest clasts are angular to subrounded boulders of dolomite as much as $1.2 \mathrm{~m}$ long; most clasts larger than $10 \mathrm{~cm}$ are mudstone, shale, and dolomite. Clasts also include minor gray chert, red quartzite, and gabbro or diorite derived from unknown sources; black, glassy chert possibly derived from the Monterey Formation; and angular, irregularly-shaped clasts of bioturbated fine-grained sandstone and siltstone possibly derived from the associated sandstone and (or) siltstone units (Qss, QTst).

Unit also includes: (1) bioturbated siltstone and sandstone; (2) laminated, fine- to coarse-grained sandstone; and (3) thin-bedded sandstone and mudstone. Bioturbated siltstone and poorly sorted, very fine to fine-grained sandstone are friable to moderately hard, brown to gray and blue-gray on freshly broken surfaces, weather gray to tan with some orange and yellow mottling, and occur in beds ranging in thickness from a few centimeters to more than $2 \mathrm{~m}$. Some beds contain scattered granules, pebbles, and cobbles, thin lenses of conglomerate, and molluscan shells and shell fragments. Fractures commonly are partly filled by jarosite. Bioturbation is defined by textural and color mottling and by knobby, irregular weathering surfaces.

Laminated, fine- to coarse-grained sandstone is gray on fresh surfaces, weathers light brown to tan, is poorly to well sorted, and ranges from friable to hard. Hard sandstone is variably calcareous and forms prominent ledges. Sandstone forms lenses within conglomerate and laterally persistent beds less than $50 \mathrm{~cm}$ to $5 \mathrm{~m}$ thick. Most beds are amalgamated; some marked by thin gray-brown clay-rich horizons up to $3 \mathrm{~cm}$ thick. Some beds exhibit normal grading from pebbly and granular sandstone at base to fine sandstone at top. Sedimentary structures include plane lamination, ripple cross lamination, convolute lamination, and low-angle scour and fill; basal bed surfaces commonly are erosional. Granules, pebbles, and cobbles of mudstone and dolomite apparently derived from Sisquoc and (or) Monterey Formations are common as scattered clasts and in lenses of conglomerate.

Intervals of thin-bedded sandstone and mudstone are poorly exposed and generally $1-5 \mathrm{~m}$ thick. Sandstone is friable, very fine to fine-grained, generally well sorted, and weathers white to light brown. Sandstone beds are 5-20 cm thick and interstratified with beds of mudstone $1-3 \mathrm{~cm}$ thick. Many sandstone beds exhibit irregular, gradational, and apparently bioturbated contacts with underlying and overlying mudstone beds; some have abrupt erosional lower contacts. Sedimentary structures include plane lamination, ripple cross lamination, and convolute lamination. Some sandstone beds exhibit partial Bouma sequences that may represent turbidites. Local observations on ripple cross laminations suggest paleoflow generally to the west and southwest. Mudstone is gray to brown, clayey and silty, bioturbated, and generally harder and more consolidated than interlayered sandstone.

Unit is inferred to have been deposited in a submarine canyon or channel eroded into underlying units. Width of channel as exposed in sea cliff is about $610 \mathrm{~m}$. Eastern contact 
of unit with Sisquoc Formation (Tsq) is a west-dipping buttress unconformity; western contact with underlying sandstone unit (Qss) is an east-dipping buttress unconformity. Both contacts are abrupt, irregular, and clearly erosional. Unit is unconformably overlain by marine-terrace deposits. Base of unit in thickest, axial part of channel is not exposed; minimum thickness of unit in this area is $33 \mathrm{~m}$. Preliminary evidence suggests that much of the conglomerate was deposited by submarine debris flows and/or high-density turbidity currents, whereas much of the sandstone and siltstone may have been deposited by lowdensity turbidity currents.

Locally abundant marine fossils in conglomerate and sandstone intervals consist mainly of mollusks and arthropods. Mollusks identified by W.P. Woodring and reported by Upson (1951) and Dibblee (1966) were interpreted as being late Pliocene(?) to early Pleistocene, but reinterpretation of these identifications, supplemented with museum and recent collections, by C.L. Powell, II (written commun., 2001), have found no Pliocene indicators. A single shark tooth (Carcharinus) was identified by J.D. Stewart (Natural History Museum of Los Angeles County). The fauna are distinguishable from the Santa Barbara Formation fauna only by the presence of shallow-water, open-coast taxa, and the two units are probably of similar age

Qss

Sandstone unit (lower Pleistocene?) —Laminated and bioturbated feldspathic sandstone, siltstone, and subordinate mudstone and conglomerate. Lower part of unit consists mainly of couplets of laminated sandstone and bioturbated sandstone and siltstone $30-100 \mathrm{~cm}$ thick. Laminated sandstone is gray, weathers light gray to light brown, and ranges from fine to coarse grained and moderately to well sorted; some beds contain scattered granules, pebbles, and cobbles of mudstone, shale, and dolomite derived from the Sisquoc and (or) Monterey Formations, in addition to scattered, poorly preserved molluscan shells and shell fragments. Planar to gently undulatory laminations mostly $0.5-1 \mathrm{~cm}$ thick are defined by variations in grain size and color banding and in places resemble hummocky cross-stratification. Convolute laminations are present locally. Lower contacts of laminated sandstone beds are abrupt and in places clearly scoured into the underlying bioturbated beds with up to $5 \mathrm{~cm}$ erosional relief. Bioturbated sandstone and siltstone are fine to medium grained, moderately to poorly sorted, gray to brown on freshly broken surfaces, weather light brown, and are generally softer and less resistant than the laminated sandstone. Bioturbation is defined by textural and color mottling; individual burrows are well preserved in some beds and exhibit vertical, horizontal, and oblique orientations. Where weathered, both laminated and bioturbated beds are soft and friable and contain abundant jarosite along fractures.

Poorly exposed intervals of white- to tan-weathering and friable to well-consolidated sandstone overlie laminated sandstone beds. Beds are 5-100 cm thick but generally less than $50 \mathrm{~cm}$ thick; most are lenticular. Some beds appear to be massive but others exhibit planar and (or) convolute lamination.

Conglomerate constitutes 1-2 percent of unit and occurs mainly as lenses $10-50 \mathrm{~cm}$ thick and less than $5 \mathrm{~m}$ in lateral extent. Most clasts are angular to subrounded granules and pebbles less than $5 \mathrm{~cm}$ long, although some are as long as 30-50 cm. Most clasts are laminated shale, mudstone, porcelanite, and dolomite derived from the Sisquoc and (or) Monterey Formations. Benthic foraminifers from one mudstone clast indicate derivation from lower part of the Monterey Formation (Tml) (R.S. Boettcher and S.A. Kling, written commun., 2001).

Contact with siltstone unit (QTst) is covered by vegetation and soil but is inferred to be a fault; depositional base of unit is not exposed, and stratigraphic relation with siltstone unit is uncertain. Exposed thickness of sandstone unit is 45-60 m. Preliminary work suggests that unit may have been deposited below fair-weather wave base on a storm-dominated marine shelf, perhaps at water depths of 10-100 m.

Age of sandstone unit is uncertain owing to lack of age-diagnostic fossils. Questionable early Pleistocene age is based on general lithologic resemblance of conglomerate, sandstone, and siltstone in unit to strata of better-dated siltstone and conglomeratic units (QTst, Ocg). 
Siltstone unit (lower Pleistocene and upper Pliocene?)—Siltstone, mudstone, and silty, very fine to fine-grained sandstone; moderately hard, dark gray-brown to brown on freshly broken surfaces, weathering light brown to gray, massive and extensively bioturbated. Stratification is generally indistinct and, where visible, poorly defined by subtle variations in color, resistance to weathering, and types and relative abundance of trace fossils; individual beds generally range from about $10 \mathrm{~cm}$ to $1 \mathrm{~m}$ or more in thickness. In places, siltstone and sandstone contain abundant mica and (or) fragments of land plants. Pebbles and granules of rock fragments are uncommon and include dolomite derived from the Sisquoc and (or) Monterey Formations and porphyritic dacitic rock of unknown derivation. Scattered, poorly preserved mollusk shells and shell fragments suggest shelf deposition, or possibly deeper. The bivalve mollusk Cylocardia sp., and gastropods Amphissa reticulata Dall, Antiplanes sp., and Exilioidea sp. are present in unit, but they are not age diagnostic (C.L. Powell II, written commun., 2001). Modern representatives of these taxa coexist in the coastal waters of southern California at depths between about 60 and $200 \mathrm{~m}$. Microfossils are abundant in the unit and include benthic foraminifers, ostracodes, and sponge spicules. Jarosite and gypsum are locally abundant along fractures. Locally, unit is cut by asphalt-filled fractures, some of which may represent exhumed conduits or "feeder dikes" in which oil migrating from source rocks at depth reached the surface and created accumulations of asphalt (Qas).

Contact with Sisquoc Formation (Tsq) is covered by landslide deposits and asphalt (Qas) and may be a fault. Depositional base of siltstone unit is not exposed, but general discordance between gently dipping beds of unit and more steeply dipping beds of older Sisquoc Formation suggests an unconformable relation. Unit is unconformably overlain by marine terrace deposits ( $\mathrm{Omt}$ ). Exposed thickness is about $45 \mathrm{~m}$.

Contains benthic foraminiferal assemblages indicative of Wheelerian Stage (of Natland, 1952; and Kleinpell, 1980) and upper to middle bathyal (150-2,000 m) water depths (R.S. Boettcher, written commun., 2001). Wheelerian Stage is considered very latest Pliocene and early Pleistocene in age (McDougall and Lagoe, 1993, p. 7; K.A. McDougall, USGS, written commun., 2001).

Sea cliffs formed by unit about $2.1 \mathrm{~km}$ east of Goleta Pier are actively eroding; some man-made structures along the tops of the cliffs have been undermined by erosion. In places, outcrops of unit are partly covered by sea walls and retaining walls.

Poorly exposed strata along the western More Ranch fault system on Mescalitan Island (near Santa Barbara Airport) and in the cliffs southwest of Goleta Slough are assigned to siltstone unit because they are lithologically similar to exposures east of Goleta Pier, and because samples yielded benthic foraminiferal assemblages indicative of Wheelerian Stage and upper bathyal to upper-middle bathyal (150-1,500 m) water depths (R.S. Boettcher, written commun., 2001; 2002). Fine-grained sedimentary rocks on the southeast side of Goleta Valley just south of Atascadero Creek (mapped as QTst?) questionably assigned to the siltstone unit owing to very poor exposures and lack of biostratigraphic ages

Tsq Sisquoc Formation (lower Pliocene and upper Miocene)—Marine diatomaceous mudstone and shale, conglomerate, and subordinate dolomite. Distinguished from the underlying upper siliceous unit of the Monterey Formation (Tmu) by the occurrence of prominent, thick beds of conglomerate composed of angular clasts derived from the Monterey, and by contrasting assemblages of fossil diatoms. Distinguished from the underlying unnamed shale unit (Tu) by the presence in the unnamed unit of laterally persistent beds of phosphatic pebble conglomerate, and by an abrupt upward change from darker-colored, hard, predominantly fine-grained strata to light-colored, relatively soft conglomerate and diatomaceous mudstone.

Diatomaceous mudstone and shale are tan to white weathering, gray to brown on freshly broken surfaces, and contain zones of fractures lined with common to abundant jarosite and gypsum. Mudstone is generally soft to moderately hard; shale ranges from soft to hard and brittle. Both mudstone and shale are generally of conspicuously low density. Reaction in dilute hydrochloric acid $(\mathrm{HCl})$ ranges from weak to strong, indicating the presence of variable amounts of carbonate minerals. Foraminifers, diatoms and diatom debris 
(in some cases with opaline luster), fish fragments, radiolarians, sponge spicules, and molluscan shells and shell fragments are common to abundant, particularly along surfaces that are broken parallel to stratification. Most mudstone and shale beds are moderately to strongly laminated but some are massive and bioturbated. Laminations, generally $0.5-10.0 \mathrm{~mm}$ thick, are defined by light and dark color bands, and variations in the types and abundance of microfossils and microfossil debris. Some cream-colored laminae may be phosphatic. Laminations within some beds are deformed into soft-sediment folds with amplitudes and wavelengths of a few centimeters to a few tens of centimeters. In places, such as the Goleta Point area, strongly fractured mudstone exhibits hydrocarbon staining and a petroliferous odor. At Coal Oil Point, mudstone and shale within the stratigraphically lowest $80-100 \mathrm{~m}$ of the Sisquoc Formation are hard, brittle, and porcelaneous.

Dolomite constitutes less than 1 percent of the formation and forms laterally persistent beds generally less than $30 \mathrm{~cm}$ thick, ranging to $100 \mathrm{~cm}$ thick, and ellipsoidal to spheroidal concretions as much as about $100 \mathrm{~cm}$ in longest dimension. Dolomite is very hard, gray on freshly broken surfaces, weathers white to light orange or light brown, and is aphanitic to sugary in texture. Some is strongly calcareous. Laminations, mostly $1-10 \mathrm{~mm}$ thick but as much as $20 \mathrm{~mm}$ thick, are defined by alternating light and dark color banding and by subtle variations in texture. Some distinctive cream-colored laminations may be phosphatic. In some beds, the laminations are involved in small-scale, disharmonic folds with wavelengths and amplitudes of a few centimeters to tens of centimeters that are interpreted to reflect soft-sediment deformation. Fish fragments and poorly preserved microfossils, including foraminifers, are common.

Conglomerate consists mainly of angular to subrounded clasts of mudstone, shale, dolomite, porcelanite, and phosphorite apparently derived from the underlying Monterey Formation. Clasts range from granules to boulders; most are smaller than $30 \mathrm{~cm}$ but blocks up to $1 \mathrm{~m}$ across are common and the largest blocks are more than $10 \mathrm{~m}$ across. In most outcrops, the largest blocks are composed of hard, laminated dolomite or porcelanite, whereas shale and mudstone blocks are generally smaller. Most conglomerate beds are about $10 \mathrm{~cm}$ to $5 \mathrm{~m}$ thick and some may be as thick as $10-20 \mathrm{~m}$. Laminated clasts typically are oriented at various angles to each other and bedding. However, some large, elongate clasts are parallel or subparallel to stratification. In many places the clasts are tightly packed; the matrix between the clasts, where present, is massive, diatomaceous mudstone. Conglomerate beds are easily recognized in fresh exposures along sea cliffs but are difficult to recognize in weathered or strongly fractured exposures. Conglomerate is well exposed in sea cliffs about 3.5-4 km east of Goleta Pier, in sea cliffs between Goleta Point and Goleta Beach County Park, in sea cliffs and the intertidal zone from Coal Oil Point to Isla Vista, and in sea cliffs between Dos Pueblos Canyon and Eagle Canyon. Conglomerate is present but poorly exposed in sea cliffs east of Bell Canyon and in sea cliffs between Ellwood and Coal Oil Point.

Samples from the lower part of the Sisquoc Formation in coastal outcrops near the mouth of Dos Pueblos Canyon, east of the mouth of Eagle Canyon, and near Goleta Pier contain diatoms of the Thalassiosira miocenical Nitzschia miocenica Assemblage Zone (upper Miocene, about 6.2-6.7 Ma) (J.A. Barron, USGS, oral and written commun., 2001, 2002). Samples from the upper part of the Sisquoc Formation at Rocky Nook Park (west end of Mission Ridge) and from a coastal exposure near the University of California, Santa Barbara, yielded diatoms of the Thalassiosira oestrupii Zone (lower Pliocene, younger than 5.5 Ma) (J.A. Barron, oral and written commun., 2002, 2005). Diatoms of early Pliocene age have been previously reported from the upper part of the Sisquoc Formation in coastal exposures southeast of Dos Pueblos Canyon (Arends and Blake, 1986; Blake, 1994, p. 19).

At several localities in the Goleta quadrangle, the contact between the Sisquoc Formation and the underlying Monterey Formation is abrupt and is placed at the base of the stratigraphically lowest thick bed of conglomerate; this lithologic change appears to coincide with boundary between T. miocenica/N. miocenica Assemblage Zone and the underlying Rouxia californica Partial Range Zone (upper Miocene, about 6.7-7.6 Ma) (J.A. Barron, personal commun., 2001) and is interpreted herein as a regional unconformity. 
In sea cliff exposures about 300-750 m west of the mouth of Eagle Canyon, the Sisquoc Formation rests with angular unconformity on the middle unit of the Monterey Formation (unit Tmm), consists mainly of boulder conglomerate, and apparently represents the fill of a large channel or submarine canyon that was incised into the Monterey Formation (Hornafius, 1994b, p. 10-11). In an exposure in the sea cliff about $600 \mathrm{~m}$ southeast of the mouth of Dos Pueblos Canyon, the unconformable contact between the Sisquoc Formation and the underlying, unnamed upper Miocene mudstone unit ( $\mathrm{Tu}$ ) is exposed and is marked by an abrupt change from dark-colored strata (mainly shale, mudstone, porcelanite, and phosphatic pebble conglomerate) of unit Tu to overlying, lighter-colored strata (mainly conglomerate and diatomaceous mudstone) of the Sisquoc Formation. This contact was previously interpreted as the boundary between the Sisquoc and Monterey Formations (Hornafius (1994a, fig. 10, p. 119) and has also been interpreted as a regionally significant sequence boundary within the Sisquoc Formation (the "surface at 1,282 feet" of Bohacs and Schwalbach, 1994, p. 93).

Most rocks mapped in this study as Sisquoc Formation were previously mapped as Monterey Formation (Upson, 1951), unnamed upper Pliocene formation (Upson, 1951), Santa Margarita Shale (Bailey, 1952; Dibblee, 1966), Sisquoc Formation (Dibblee, 1966), and Sisquoc Shale (Dibblee, 1987a, 1987b). Some rocks previously mapped as Monterey Shale (Dibblee, 1966) and Monterey Formation (Dibblee, 1986b, 1987a, 1987b) are herein included in the Sisquoc Formation.

Thickness of the Sisquoc Formation in map area is uncertain because the upper part of the unit was removed by erosion prior to deposition of the overlying Santa Barbara Formation (Qsb), unnamed sedimentary rocks east of Goleta Pier (Qcg, Oss, and QTst), and marine terrace deposits (Qmt). The Sisquoc is at least 250-300 m thick in the Goleta Pier area (Dibblee, 1966, p. 51) and at least $140 \mathrm{~m}$ thick along the coast southeast of Dos Pueblos Canyon.

Organic content in Sisquoc is locally great enough for unit to qualify as a potential hydrocarbon source in region (Tennyson and Isaacs, 2001). In certain coastal areas, most notably Isla Vista, wave-aided erosion of sea cliffs underlain by the Sisquoc Formation has undermined buildings and exposed parts of their foundations

Unnamed mudstone (upper Miocene)_-Marine mudstone, shale, and porcelanite with subordinate dolomite and phosphatic pebble conglomerate. Mudstone and shale are brown to dark gray on fresh surfaces, weather orange- to red-brown, and in places have a strong hydrocarbon odor. Mudstone and shale are hard, brittle, siliceous, laminated to massive and bioturbated, and contain diatoms and fish fragments. Granules, pebbles, and rare cobbles of angular to rounded phosphorite, dolomite, and porcelanite that presumably were derived from erosion of the underlying Monterey Formation are scattered in the shale and mudstone. Rare sandstone clasts of unknown origin also are present. Some clasts exhibit pholad borings, suggesting prolonged exposure on the ancient sea floor. The largest clasts are about $15-20 \mathrm{~cm}$ across, but most clasts are less than $10 \mathrm{~cm}$ across. Sandstone clasts are well rounded and approximately spheroidal in shape, whereas the clasts of porcelanite and phosphorite are irregular in shape and angular to subrounded. Porcelanite and dolomite in the unnamed unit are generally thin-bedded and similar in lithology to porcelanite and dolomite in the underlying Monterey Formation.

Pebble conglomerate occurs mainly in the lower part of the unnamed unit and contains clasts of mudstone, porcelanite, chert, phosphorite, and dolomite; most clasts are irregular in shape and angular to subrounded. Rare cobbles and boulders are also present. Conglomerate exhibits both clast-supported and matrix-supported textures. Where visible, the matrix consists of hard, apparently siliceous silty mudstone. Conglomerate beds are generally about $10-50 \mathrm{~cm}$ thick and lenticular; no beds can be traced laterally for more than about $20 \mathrm{~m}$. The lower contacts of most conglomerate beds are sharp, irregular, and scoured into the underlying mudstone beds. The clasts in some conglomerate beds are imbricated and suggest paleoflow generally toward the south.

Samples of siliceous shale from the unnamed mudstone unit provided no useful biostratigraphic information (J.A. Barron, written commun., 2002). Nevertheless, the 
unnamed unit is upper Miocene based on well-dated upper Miocene strata in both the overlying Sisquoc Formation and underlying Monterey Formation.

The contact between the unnamed unit and the underlying Monterey Formation is exposed in the sea cliff about $600 \mathrm{~m}$ southeast of the mouth of Dos Pueblos Canyon. At this locality, the contact is a scoured surface with about $10-20 \mathrm{~cm}$ of erosional relief that is directly overlain by a bed of pebble conglomerate that contains clasts of phosphorite and porcelanite. This contact, although having no color change associated with it, is interpreted as an unconformity. Previously, the lower contact of the unnamed unit was interpreted as a sequence boundary that separates the Sisquoc and Monterey Formations in this area (the "surface at 1,237 feet" of Bohacs and Schwalbach, 1994, p. 93).

Strata that are herein assigned to the unnamed unit were included in the lower part of the Sisquoc Formation by Bohacs and Schwalbach (1994), in the upper part of the Monterey Formation by Hornafius (1994a, 1994b), and in the Sisquoc Shale and Monterey Formation by Dibblee (1987a). Exposures of the unnamed unit are restricted to the coastal area southeast of the mouth of Dos Pueblos Canyon, where it is about 15-20 m thick. The lateral extent and thickness of the unnamed unit may have been greater prior to late Miocene erosion and subsequent deposition of the Sisquoc Formation

Monterey Formation (Miocene) - Marine, predominantly well-bedded, siliceous and calcareous mudstone and shale with subordinate porcelanite and dolomite. The Monterey Formation is well exposed in sea cliffs in the western half of the map area and southeast of Carpinteria; however, the Monterey generally is poorly exposed and highly weathered, with many original lithologic details obscured, where it crops out inland in low hills north of Goleta and in the La Mesa, Hope Ranch, and Mission Ridge areas. The Monterey Formation is of Miocene age on the basis of abundant biostratigraphic data from microfossils (Dibblee, 1966; Ingle, 1980, and references therein; Arends and Blake, 1986; Barron, 1986; DePaolo and Finger, 1991; Blake, 1994; Hornafius, 1994a, 1994b, and references therein). The Monterey Formation is about 370-390 m thick near the mouth of Dos Pueblos Canyon; elsewhere in the map area, the thickness of the Monterey Formation cannot be reliably determined because of poor and discontinuous exposure, complicated structure, and erosion. The maximum, composite thickness of the formation is estimated to be about $830 \mathrm{~m}$ based on maximum thicknesses of Monterey subunits exposed at several different locations. Organic contents in rocks of the Monterey Formation are generally high and the unit is a major potential hydrocarbon source in the region (Tennyson and Isaacs, 2001). Also, highly fractured zones within the formation form localized oil reservoirs (Tennyson and Isaacs, 2001).

The Monterey Formation is divided into three subunits that are distinguished from each other by lithology and age: an upper siliceous unit, a middle shale unit, and a lower calcareous unit. The upper siliceous unit (Tmu) consists mainly of soft to moderately hard diatomaceous mudstone and shale in the area east of Eagle Canyon, but west of Eagle Canyon the unit consists mainly of hard siliceous shale and porcelanite. The middle shale unit (Tmm) is lithologically diverse and consists of interstratified siliceous and calcareous shale, mudstone, porcelanite, and phosphorite. The lower calcareous unit (Tml) consists mainly of calcareous mudstone and shale. Microfossil assemblages, mainly diatoms, calcareous nannofossils, and benthic foraminifers, indicate that the upper unit is of late Miocene age, the middle unit of late and middle Miocene age, and the lower unit of middle and early Miocene age

Upper siliceous unit (upper Miocene)—East of Eagle Canyon, the upper siliceous unit consists mainly of diatomaceous mudstone and shale with subordinate dolomite and porcelanite. Mudstone and shale generally weather white to tan, have a slight red to orange cast in places where hydrocarbon staining is present, and are generally brown to gray on fresh surfaces. The rocks are soft to moderately hard, less resistant to weathering than dolomite and porcelanite, noticeably low density, and locally exhibit numerous fractures coated with abundant jarosite and goethite(?). Variable reactions to dilute $\mathrm{HCl}$ indicate the presence of variable amounts of carbonate minerals. Microfossils are abundant, generally well preserved, and include diatoms, foraminifers, and fish fragments; in places, freshly broken surfaces of diatomaceous mudstone reveal many diatom tests with opaline luster. Mudstone 
and shale are generally thin to thick bedded and well laminated; the laminations are generally $0.5-20 \mathrm{~mm}$ thick and are defined by color banding ranging from nearly white to dark gray-brown, variations in the types and abundance of microfossils, and parallel alignment of flat particles, mainly fish scales and diatom tests. Rarely beds include cream-colored phosphatic laminations and (or) oblate phosphatic nodules as much as $1 \mathrm{~cm}$ thick and $5 \mathrm{~cm}$ long, with the longest dimension usually parallel to bedding. In places, the mudstone and shale exhibit hydrocarbon staining and a strong petroliferous odor.

Dolomite concretions and beds constitute about 5-10 percent of the unit. The concretions are ellipsoidal to spheroidal, generally $10-50 \mathrm{~cm}$ thick and less than $2.5 \mathrm{~m}$ long, and usually oriented with the long axis parallel to stratification. The beds are generally laterally persistent and mostly about $10-100 \mathrm{~cm}$ thick but in places are more than $200 \mathrm{~cm}$ thick. Dolomite is very hard and brittle, relatively resistant, brown to gray on fresh surfaces, generally weathers white with a slight orange or yellow cast, and is aphanitic to sugary in texture. Reaction of the dolomite in dilute $\mathrm{HCl}$ ranges from none to weak. Laminations in the dolomite are common and resemble those in the associated mudstone and shale. In some cases, laminations in dolomitic concretions pass laterally into mudstone and shale. Microfossils, including foraminifers and fish fragments, are abundant in the dolomite but generally poorly preserved. In many places, the dolomite is strongly fractured and in some exposures brecciated; some fractures are filled by white minerals of unknown composition, whereas other fractures are filled by hydrocarbons.

East of Eagle Canyon and north of the Isla Vista fault, porcelanite is present only in the stratigraphically lower part of the upper siliceous unit and occurs as isolated, resistant beds about $5-50 \mathrm{~cm}$ thick that are sporadically interstratified with diatomaceous mudstone and shale. The porcelanite is hard and brittle, gray to brown on fresh surfaces, weathers tan to white, is generally noncalcareous, and exhibits conchoidal fracture and porcelaneous luster. The porcelanite is generally well laminated and contains abundant but poorly preserved microfossils, including foraminifers. In places, the porcelanite is strongly fractured and stained by hydrocarbons.

West of Eagle Canyon, the upper siliceous unit consists mainly of thin-bedded, siliceous mudstone and shale, porcelanite, and subordinate dolomite. The mudstone and shale are hard, brittle, thin-bedded, brown on fresh surfaces, weather light brown, contain fish fragments and poorly preserved diatoms, occur in beds generally about $5-30 \mathrm{~cm}$ thick, and usually react weakly or not at all with dilute $\mathrm{HCl}$. Porcelanite is hard and brittle, commonly highly fractured, dark gray to brown on fresh surfaces, weathers gray and light brown to white, exhibits conchoidal fracture, and occurs in beds that are generally $5-20 \mathrm{~cm}$ thick and slightly more resistant than mudstone and shale. Dolomite is generally very hard and more resistant to weathering than porcelanite, mudstone, and shale. Dolomite weathers orange- to yellow-brown, is gray brown on fresh surfaces, generally exhibits a weak reaction in dilute $\mathrm{HCl}$, and occurs as concretions and as beds that are well-laminated and generally about $30-50 \mathrm{~cm}$ thick.

Published biostratigraphic studies of coastal outcrops near Dos Pueblos Canyon indicate that the upper siliceous unit in that area contains diatoms and benthic foraminiferal assemblages of late Miocene age (Arends and Blake, 1986; Barron, 1986; Hornafius, 1994a, 1994b; Blake, 1994). Farther east, samples from coastal outcrops of the upper siliceous unit near the mouth of Bell Canyon, near Ellwood, and near Goleta Pier yielded benthic foraminiferal assemblages that probably represent the upper part of the Mohnian Stage of Kleinpell $(1938,1980)$ and upper bathyal to upper middle bathyal $(150-1,500 \mathrm{~m})$ water depths (R.S. Boettcher, written commun., 2001; K.A. McDougall, written commun., 2004), and diatom assemblages of the Rouxia californica Partial Range Zone, Thalassiosira antiqua Zone, and Denticulopsis hustedtii Zone, all of late Miocene age (Barron, 1986; J.A. Barron, written commun., 2001-2005). Within the City of Santa Barbara, samples of the upper siliceous unit from road cuts and natural outcrops in the vicinities of Franceschi Park, Sycamore Canyon, and Lou Dillon Lane yielded diatoms of the middle upper Miocene, lowermost part of the Thalassiosira antiqua Zone (ca. 8.5 Ma), the upper Miocene Denticulopsis hustedtii Zone (=D. katayamae Zone) (8.6-9.2 Ma), and the lower upper Miocene Denticulopsis dimorpha Zone (9.2-9.9 Ma) ( J.A. Barron, written 
commun., 2003-2005). The available data imply that the base of the upper siliceous unit increases in age from west to east, from about 8.0-8.5 Ma in the vicinity of Dos Pueblos Canyon (Hornafius, 1994a) to about 9.2-9.9 Ma or older near Franceschi Park.

The upper siliceous unit rests conformably and sharply on the middle shale unit (Tmm). The contact between the two units is well exposed in the sea cliff about $5.4 \mathrm{~km}$ east of Goleta Pier and is placed at base of a prominent $40-\mathrm{cm}$-thick dolomite bed that overlies a prominent horizon of dark, platy, phosphatic shale that is highest known stratigraphic position of conspicuously phosphatic shale in Monterey Formation in this area. In the sea cliff south of Ellwood, the contact between the upper and middle units is placed at the base of a prominent, white-weathering, 200 -cm-thick dolomite bed that separates white-weathering diatomaceous mudstone of the upper siliceous unit from underlying, darker-colored, diatomaceous and phosphatic mudstone, porcelanite, and dolomite of the middle shale unit. In the sea cliff near Dos Pueblos Canyon, the contact between the upper siliceous and middle shale units is placed at a prominent change in lithology marked by an abrupt upward increase in the frequency and thickness of porcelanite beds.

Rocks assigned herein to the upper siliceous unit previously were mapped as Monterey Shale (Upson, 1951; Lian, 1954), upper Monterey Shale (Dibblee, 1966), lower shale unit of the Monterey Formation (Dibblee, 1986b), upper shale unit of the Monterey Formation (Dibblee, 1986b, 1987a, 1987b), and Sisquoc Shale (Dibblee, 1987a). The thickness of the upper siliceous unit appears to increase eastward from about 50-60 m near Dos Pueblos Canyon to about 160-180 m near Ellwood and about $250 \mathrm{~m}$ in the vicinity of Goleta Pier. The upper siliceous unit is well exposed along sea cliffs in the Dos Pueblos and Goleta quadrangles, where it forms bright, white-weathering dip slopes; small landslides and rock falls are common along these slopes, but the upper siliceous unit is generally more resistant to erosion and less susceptible to landsliding than the underlying middle shale unit. In inland upland areas, the upper siliceous unit is generally poorly exposed and mostly covered by colluvium and dense vegetation.

Small area of siliceous shale on the southeast side of Goleta Valley just south of Atascadero Creek questionably assigned to the upper siliceous unit (mapped as Tmu?) owing to very poor exposure and lack of a biostratigraphic age determination. In the intertidal zone at Coal Oil Point, thin-bedded strata consisting mainly of hard, siliceous shale, porcelanite, and dolomite are visible during low tides. These strata are herein questionably assigned to the upper siliceous unit of the Monterey Formation (mapped as Tmu?) but, alternatively, may instead be correlative with the unnamed mudstone unit $(\mathrm{Tu})$

$\mathrm{Tmm}$

Middle shale unit (upper and middle Miocene) —Shale, mudstone, dolomite, porcelanite, phosphorite, and subordinate tuff, typically exposed in white-weathering dip slopes along sea cliffs. Shale and mudstone are variable in outcrop appearance, which reflects varying proportions of siliceous, calcareous, phosphatic, organic, and argillaceous components; some are highly calcareous and react vigorously in dilute $\mathrm{HCl}$, whereas some dark-colored, apparently organic-rich shales react weakly or not at all. Siliceous and calcareous shale and mudstone typically are hard and brittle, commonly fissile to platy weathering, and relatively resistant to weathering; phosphatic, organic-rich, and clay-rich shales and mudstones are generally less hard and less resistant, and range from hackly to fissile weathering. Shale and mudstone generally weather white to tan; some phosphatic- and organic-rich shales and mudstones weather reddish-brown. Shale and mudstone of all compositions are brown to dark brown on fresh surfaces, and commonly are well laminated and thin to medium bedded; most beds are less than $30 \mathrm{~cm}$ thick, but some are $100 \mathrm{~cm}$ thick or more. Most beds are laminated; in places, the laminations show subtle low-angle truncations that probably represent scour-and-fill processes on the sea floor and can be used as top-bottom indicators. Most laminae are planar and parallel to each other but some horizons exhibit small-scale, disharmonic and isoclinal folds that probably represent soft-sediment deformation. A prominent submarine slump deposit with a minimum thickness of $20-30 \mathrm{~m}$ is well exposed in the sea cliff about $0.5 \mathrm{~km}$ east of the mouth of Eagle Creek. In places, shale and mudstone contain abundant microfossils visible with hand lens, including foraminifers and fish scales. Diatoms are visible in the upper part of the unit at certain localities, including coastal exposures near Ellwood. In places, foraminifers are concentrated 
in sandy-textured lenses; these lenses fill shallow scours that truncate lamination in the underlying strata and thereby aid in determining the direction of stratigraphic top. Creamto white-colored phosphatic laminae, generally 1-10 mm thick, and phosphatic nodules up to $5 \mathrm{~cm}$ across, are locally abundant in the shale and mudstone, particularly in darker-colored, less-resistant horizons. Interbeds and concretions of dolomite range in thickness from a few $\mathrm{cm}$ to about $300 \mathrm{~cm}$ and are similar in lithology to dolomite in the upper siliceous unit.

Porcelanite is generally hard and brittle, relatively resistant to erosion, weathers tan or gray to nearly white, is dark gray or dark brown to black on freshly-broken surfaces, shows conchoidal fracture and porcelaneous luster, and exhibits a reaction to dilute $\mathrm{HCl}$ ranging from none to very strong. Most beds are well-laminated and, where observed in large outcrops, persist for tens to hundreds of meters along strike; beds range from a few $\mathrm{cm}$ to about $40 \mathrm{~cm}$ thick, but some beds exceed $100 \mathrm{~cm}$. Laminae of black, glassy chert are present in places, including coastal exposures southwest of Ellwood. Some beds contain abundant foraminifers and fish scales that are visible with a hand lens. In some inland exposures the foraminifers have been removed by dissolution, leaving behind small holes that preserve the shapes of the foraminifers. In places, porcelanite is strongly fractured, and the fractures are partly or completely filled by dark-colored asphaltic material with a strong petroliferous odor; locally the porcelanite is brecciated. In western sea cliff exposures, the relative proportion of porcelanite in the middle shale unit increases westward and generally upsection from about 5 percent near Tecolote Canyon to nearly 50 percent west of Eagle Canyon.

Phosphatic hardgrounds and conglomerate in the middle shale unit are well exposed in the sea cliff near the mouth of Dos Pueblos Canyon and are described in detail by Garrison and others (1994) and Föllmi and others (2005). A poorly-exposed occurrence of phosphatic conglomerate associated with porcelanite and shale was noted in a road cut in Sycamore Canyon.

Tuff is present sporadically as single, laterally-persistent beds, generally $1-5 \mathrm{~cm}$ thick but locally $25 \mathrm{~cm}$, that range from soft and friable to hard, and that weather to a variety of colors including orange, green, cream, gray, and white. The tuff is generally aphanitic but in places exhibits a silty to very fine sandy texture and contains crystals of biotite(?).

Published biostratigraphic studies of assemblages of diatoms and foraminifers, summarized by Hornafius (1994a, 1994b), show that the middle shale unit along the coast near Dos Pueblos Canyon was deposited about 8.0-14.5 Ma. Samples from outcrops of the middle shale unit along the coast from near Eagle Canyon to near Tecolote Canyon yielded benthic foraminiferal assemblages indicative of the Mohnian Stage of Kleinpell $(1938,1980)$ and upper bathyal to middle bathyal $(150-2,000 \mathrm{~m})$ water depths, and calcareous nannofossils of probable late Miocene age that could not be assigned to specific zones (R.S. Boettcher and S.A. Kling, written communs., 2002). Samples from sea cliff exposures of the middle shale unit on the north side of the More Ranch fault, about $1.1 \mathrm{~km}$ southeast of the mouth of Tecolote Canyon, yielded benthic foraminiferal assemblages indicative of the Mohnian Stage of Kleinpell $(1938,1980)$ and upper middle bathyal to lower middle bathyal (500-2,000 m) water depths, and calcareous nannofossils of the probable CN5a zone of middle Miocene age (R.S. Boettcher, S.A. Kling, and K.A. McDougall, written communs., 2003, 2004). Samples of the middle shale unit from coastal exposures southwest of Ellwood yielded benthic foraminiferal assemblages indicative of the Mohnian Stage of Kleinpell $(1938,1980)$ and upper middle bathyal $(500-1,500 \mathrm{~m})$ water depths, and calcareous nannofossils of probable late Miocene age that could not be assigned to specific zones (R.S. Boettcher and S.A. Kling, written communs., 2003). A sample from the uppermost part of the middle shale unit about $5.4 \mathrm{~km}$ east of Goleta Pier yielded benthic foraminifers indicative of the Mohnian Stage, possibly upper Mohnian, of Kleinpell $(1938,1980)$ and probable upper middle bathyal water depths (R.S. Boettcher, written commun., 2001). Samples from the Hope Ranch and Arroyo Burro areas yielded lower Mohnian benthic foraminifers suggestive of middle bathyal (500-2,000 m) water depths, as well as calcareous nannofossils of probable late Miocene age (R.S. Boettcher and S.A. Kling, written communs., 2001). 
According to Hornafius (1994a, p. 123), the boundary between the Mohnian and Luisian benthic foraminiferal stages exposed in the sea cliff about $2.1 \mathrm{~km}$ east of the Arroyo Burro Beach Park parking lot is associated with a prominent, white-weathering dolomite bed in the lowermost part of the unit. A few meters to the east of this locality and slightly downsection, the conformable contact between the middle shale unit and the underlying lower calcareous unit is placed at the base of a prominent, thick interval of porcelanite (the "massive chert member" of Hornafius, 1994a, p. 120-123). Elsewhere in the map area, the depositional contact between the middle shale and lower calcareous units is not exposed.

Rocks mapped as middle shale unit in this report were previously mapped as Monterey Shale (Upson, 1951; Lian, 1954), upper Monterey Shale (Dibblee, 1966), lower Monterey Shale (Dibblee, 1966), lower shale unit of Monterey Formation (Dibblee, 1986b, 1987a), upper shale unit of Monterey Formation (Dibblee, 1986b, 1987a, 1987b), and Sisquoc Shale (Dibblee, 1987a). The middle shale unit of this report includes all of the middle shale and massive chert members and part or all of upper chert member of Hornafius (1994a, p. 121-122). The thickness of the middle shale unit along the coast near Dos Pueblos Canyon is about 70-75 m; elsewhere in the map area, the thickness of the unit cannot be determined accurately owing to structural complications and the fact that many exposures are at low angles to bedding. The thickness in these areas is estimated to be about $120-180 \mathrm{~m}$.

In coastal exposures in the Goleta and Santa Barbara quadrangles, the middle shale unit is involved in several large landslides, many of which comprise large translated and partly rotated blocks of internally intact bedrock in which remnants of pre-landslide stratigraphy and structure are preserved (see also Bezore and Wills, 2000). Upland exposures of the middle shale unit, limited to lower Sycamore Canyon, are very poor and the unit is mostly covered by colluvium and vegetation

Tml Lower calcareous unit (middle and lower Miocene)—Calcareous, siliceous, and phosphatic mudstone and shale, with subordinate dolomite, porcelanite, breccia, glauconitic sandstone, and tuff. Distinguished from the underlying Rincon Shale (Tr) mainly by its well-bedded character and greater proportion of siliceous shale and mudstone, which typically are harder and more resistant to weathering than Rincon Shale.

Mudstone and shale range from moderately hard to very hard, weather white to tan, and are brown to gray brown on fresh surfaces. Mudstone and shale are well stratified and form laterally persistent beds generally $3-30 \mathrm{~cm}$ thick, but some beds are as thick as 100 $\mathrm{cm}$. Beds vary considerably in relative resistance to weathering. Reaction in dilute $\mathrm{HCl}$ is moderate to strong in most beds, indicating that they are moderately to highly calcareous. Most beds exhibit laminations ranging from 0.5 to $10 \mathrm{~mm}$ thick, which are defined by subtle variations in color and texture; some beds are massive to bioturbated. Microfossils are abundant and consist mainly of calcareous foraminifers and fish fragments. Some beds contain more than 50 percent bioclastic debris. In places, white- to cream-colored phosphatic nodules and laminae are abundant, generally about 1-10 $\mathrm{mm}$ thick and 5-25 $\mathrm{cm}$ in longest dimension, which is always parallel to bedding. Intervals of mudstone with abundant phosphatic nodules and laminae are thicker and more frequent in the upper part of the unit, and in places are as thick as $5 \mathrm{~m}$. These intervals weather white to tan, are dark gray to brown on fresh surfaces, and generally are less resistant to weathering than calcareous and siliceous mudstones.

Dolomite is very hard, resistant, weathers yellow-gray to orange-gray and light orange, and is gray to gray-brown on freshly broken surfaces. Dolomite constitutes less than 5 percent of the unit and generally occurs as beds and concretions about $10-50 \mathrm{~cm}$ thick, but some beds are as thick as $200 \mathrm{~cm}$. Concretions are ellipsoidal to irregular in shape and about 1-2 $\mathrm{m}$ in longest dimension, which is usually parallel to stratification. Most dolomite reacts slowly with dilute $\mathrm{HCl}$, but some weathered dolomite reacts strongly. Dolomite beds are often strongly fractured; veins of white to gray calcite are common and some veins are oil stained.

Porcelanite is hard, brittle, resistant, exhibits conchoidal fracture, weathers light gray to white, and is gray to brown on freshly broken surfaces. Porcelanite is present at irregular 
intervals in the unit as massive to well-laminated beds about 5-20 cm thick that increase in thickness and abundance upward in the unit. The relative amount of porcelanite is generally less than one percent but locally is as much as 25 percent. In sea-cliff outcrops, some beds of porcelanite react strongly to dilute $\mathrm{HCl}$ and contain abundant calcareous foraminifers. Lenses of black, glassy chert are present locally, for example in sea cliffs near Ellwood and in sea cliffs east of the mouth of Carpinteria Creek. In some inland exposures, porcelanite contains small holes created by dissolution of calcareous foraminifers.

At places along the sea cliffs - for example, west of the mouth of Gato Canyon, between the mouths of Las Varas and Dos Pueblos Canyons, and east of the mouth of Carpinteria Creek - the lower calcareous unit includes intervals about 1-30 m thick in which beds are gently to moderately folded, faulted, and stretched (for example, see Hornafius, 1994a, p. 118, fig. 10c); these intervals exhibit outcrop-scale, disharmonic folds with wavelengths and amplitudes of 1-10 meters, discontinuous faults with small offsets, and beds that are stretched and thinned. Much of this deformation may have formed during downslope, gravity-driven slumping of soft to partly lithified sediment shortly after deposition. In some areas, for example near the mouth of Dos Pueblos Canyon and east of the mouth of Carpinteria Creek, the slumped intervals are associated with layers of breccia that range in thickness from less than $1 \mathrm{~m}$ to about $45 \mathrm{~m}$ and consist of angular to subrounded clasts of mudstone, shale, dolomite, and porcelanite, generally about $1-100 \mathrm{~cm}$ in longest dimension but in places as large as $30 \mathrm{~m}$. In most exposures of breccia, the blocks form a clast-supported framework, and the matrix between blocks is gray to gray-brown mudstone. Some breccia intervals, however, are matrix-rich and have a mélange-like appearance in which the blocks are separated from one another by mudstone matrix. The specific processes that deposited the breccias are unclear but may have included catastrophic, gravity-driven events such as debris flows, underwater rock falls, sediment gravity flows, and downslope slumping in a submarine slope environment (Garrison and Ramirez, 1989).

Sandstone constitutes much less than 1 percent of the lower calcareous unit; a single horizon of glauconitic, medium- to fine-grained sandstone about $40-50 \mathrm{~cm}$ thick was found in the intertidal zone about $0.25 \mathrm{~km}$ southwest of Santa Barbara Point. The glauconitic sandstone horizon is hard and more resistant to weathering than the underlying and overlying horizons of calcareous mudstone. The sandstone weathers tan to orange tan, is brown to tan on freshly broken surfaces, and consists of at least three amalgamated beds that are normally graded from medium-grained sandstone at the base to fine-grained, silty sandstone at the top. The lower contact of the lowest sandstone bed with the underlying calcareous mudstone is sharp and exhibits about $10 \mathrm{~cm}$ of erosional relief. The upper part of the uppermost sandstone bed is bioturbated and grades upward into the overlying calcareous mudstone.

Tuff constitutes much less than one percent of the unit. It weathers orange-gray to yellow-gray, is gray to greenish-gray on freshly broken surfaces, and ranges from vitric to crystal-vitric with crystals of biotite and feldspar. In general, tuff forms laterally persistent, recessive beds about 1-10 cm thick; the lower bed contacts are generally sharp and apparently erosional, whereas the upper contacts are mostly bioturbated and grade into overlying calcareous mudstones. Some crystal-bearing beds of tuff are well laminated and normally graded.

Samples of mudstone from outcrops of the lower calcareous unit near the mouth of Gato Canyon yielded benthic foraminiferal assemblages indicative of the Saucesian Stage of Kleinpell $(1938,1980)$ and lower middle bathyal to lower bathyal $(>1,500 \mathrm{~m})$ water depths, and calcareous nannofossils of lower middle to lower Miocene zones CN3 to CN1 (R.S. Boettcher and S.A. Kling, written communs., 2003). Biostratigraphic, paleomagnetic, and strontium-isotopic data indicate that the lower calcareous unit near the mouth of Dos Pueblos Canyon is of early to early middle Miocene age (DePaolo and Finger, 1991; Blake, 1994; Hornafius, 1994a, 1994b). Samples of mudstone and shale from the lower calcareous unit in the sea cliff southeast of the mouth of Bell Canyon yielded benthic foraminifers indicative of the Relizian and Luisian Stages of Kleinpell $(1938,1980)$ and lower middle bathyal to upper middle bathyal (500-2,000 m) water depths (R.S. Boettcher, written commun., 2002; K.A. McDougall, written commun., 2004) and calcareous nanno- 
fossils of middle Miocene zone CN5A (S.A. Kling, written commun., 2002). Samples of mudstone from the lower calcareous unit near Santa Barbara Point yielded benthic foraminiferal assemblages indicative of the Relizian and Luisian Stages of Kleinpell (1938, 1980) and lower middle bathyal to lower bathyal water depths, calcareous nannofossils of lower middle Miocene zone CN4, and apparently reworked lower Miocene or upper Oligocene calcareous nannofossils (R.S. Boettcher and S.A. Kling, written commun., 2001). Samples of mudstone and shale from the lower calcareous unit in the sea cliff southeast of the mouth of Carpinteria Creek yielded benthic foraminifers indicative of the Relizian and Saucesian Stages of Kleinpell $(1938,1980)$ and lower middle bathyal to upper middle bathyal water depths, and calcareous nannofossils of lower middle to lower Miocene zones CN4 to CN1 (R.S. Boettcher and S.A. Kling, written communs., 2002, 2003).

The conformable contact between the lower calcareous unit and the underlying Rincon Shale is well exposed in the sea cliff near the mouth of Las Varas Canyon and is placed at the abrupt lithologic transition from well-bedded, siliceous and calcareous mudstone and shale (typical of the lower calcareous unit) to the underlying massive mudstone (typical of the Rincon Shale). In most of the map area, however, the contact between the lower calcareous unit and the Rincon Shale is faulted or covered.

Strata mapped as the lower calcareous unit in this report were previously mapped as Monterey Shale by Upson (1951) and Lian (1954), lower Monterey Shale by Dibblee (1966), lower shale unit of Monterey Formation by Dibblee (1986b, 1987a, 1987b), and upper shale unit of Monterey Formation by Dibblee (1986a, 1987a). The lower calcareous unit of this report is correlative with most or the entire lower calcareous shale member of Hornafius (1994a, p. 121-122; 1994b, p. 6). The lower calcareous unit is about $250 \mathrm{~m}$ thick near the mouth of Dos Pueblos Canyon (Hornafius, 1994b, p. 4-5). Elsewhere in the map area, the thickness of the unit cannot be reliably determined because of poor exposure and (or) complicated structure. The lower calcareous unit is well exposed along the coast but generally is poorly exposed inland. It is the only subunit of the Monterey Formation exposed in upland areas except on Mission Ridge, where it is accompanied by middle and upper Monterey subunits. Along the coast, the lower calcareous unit generally forms steep, light-colored sea cliffs with numerous small rock falls; in places, erosion of these cliffs has undermined buildings, fences, and other man-made structures

Tmlb Breccia (middle? and lower Miocene) —Intraformational breccia (Hornafius, 1994a, p. 115) exposed on the sea cliff near the mouth of Dos Pueblos Canyon. The breccia is about $30 \mathrm{~m}$ thick and consists of angular to subrounded clasts ranging from less than $1 \mathrm{~cm}$ to more than $200 \mathrm{~cm}$ across, but mostly 5-50 cm across, in a mudstone matrix. The clasts are mainly laminated, calcareous mudstone but also include weathered dolomite. According to Hornafius (1994b, p. 4), the base of this unit is approximately coincident with the boundary between the Relizian and Saucesian benthic foraminiferal stages of Kleinpell (1938, 1980)

$\operatorname{Tr} \quad$ Rincon Shale (lower Miocene)—Marine, primarily massive and thick-bedded mudstone, with subordinate dolomite, siliceous shale, sandstone, and tuff. More than 90 percent of the Rincon Shale is composed of mudstone that is gray to gray-brown on freshly broken surfaces, weathers light brown, is generally hard to moderately hard, and generally shows a moderate to weak reaction in dilute $\mathrm{HCl}$. At places, the mudstone contains abundant microfossils including calcareous foraminifers and fish scales. Mudstone is generally massive and bioturbated; some burrows in mudstone are filled by glauconitic(?) fine-grained sandstone, for example in intertidal outcrops west of Las Varas Canyon. Mudstone is thick to very thick bedded, with beds generally $30-200 \mathrm{~cm}$ thick. Typical hackly fractures in mudstone commonly contain yellow jarosite.

Dolomite is hard, resistant to weathering, gray to gray brown on freshly broken surfaces, weathers orange to yellow orange, has aphanitic to sugary texture, and reacts slowly or not at all in dilute $\mathrm{HCl}$. Dolomite forms laminated to massive, laterally-persistent beds as thick as $100 \mathrm{~cm}$, and also spheroidal to ellipsoidal concretions that range in size from a few centimeters to nearly $3 \mathrm{~m}$ across. The long axes of the dolomite concretions commonly parallel bedding. 
Uncommon sandstone forms sparse interbeds within thick sequences of mudstone. The sandstone is medium to fine grained, feldspathic, and friable. Sandstone beds, generally $5-10 \mathrm{~cm}$ thick and laterally persistent, exhibit sharp and irregular lower contacts that probably represent filled scours in the underlying mudstone and bioturbated upper contacts that grade into the overlying mudstone.

White-weathering tuff in the upper part of the Rincon Shale is exposed at several localities including the sea cliff near the mouth of Las Varas Canyon, along Mission Creek in Rocky Nook Park, in Sycamore Canyon, and road cuts in Summerland and along Conejo Drive in Santa Barbara. The tuff ranges from soft and friable to moderately indurated, consists mainly of glass shards, and in places contains fish scales as well as pumice and crystals of feldspar, quartz, and biotite. The tuff is massive to well-laminated and its apparent thickness ranges from at least $4 \mathrm{~m}$ at Rocky Nook Park to nearly $10 \mathrm{~m}$ in Sycamore Canyon. Dibblee (1966, p. 46) apparently considered these widely-separated outcrops of tuff to represent a single stratigraphic horizon that marks the base of the Monterey Formation. However, we mapped the boundary between the Rincon Shale and Monterey Formation at the lithologic transition from relatively massive and poorly bedded, predominantly argillaceous mudstone (typical of the Rincon Shale), to overlying, well-bedded, siliceous and calcareous mudstone and shale (typical of the Monterey Formation). In many places, this contact is approximately located because of poor exposure, but tuff exposed near the mouth of Las Varas Canyon is clearly at least $8 \mathrm{~m}$ (Hornafius, 1994b, p. 6) stratigraphically below the change in lithology and is, thus, included in the Rincon Shale. In places, the tuff may be entirely within the Monterey Formation; for example, tuff exposed near Lauro Canyon Dam appears to be underlain by siliceous shale typical of the Monterey Formation. Outcrop quality and available age control are insufficient to demonstrate whether the widely-separated outcrops of tuff represent a single stratigraphic horizon that was deposited during a single event or, alternatively, several closely-spaced stratigraphic horizons that were deposited during multiple events. Within the map area, a sample of tuff from a road cut in Summerland yielded a preliminary ${ }^{40} \mathrm{Ar} /{ }^{39} \mathrm{Ar}$ incremental heating age on plagioclase of 17.2-17.3 Ma (R.J. Fleck, USGS, written commun., 2005). Previously, samples of tuff from Summerland yielded K-Ar ages on plagioclase of 16.5 $\pm 0.6 \mathrm{Ma}$ and $17.2 \pm 0.5 \mathrm{Ma}$ (Turner, 1970, corrected for changes in decay constants using method of Dalrymple, 1979), and a sample of tuff from near the mouth of Las Varas Canyon yielded $\mathrm{a}^{40} \mathrm{Ar} /{ }^{39} \mathrm{Ar}$ single-crystal laser-fusion age on sanidine of $18.42 \pm 0.06 \mathrm{Ma}$ (Stanley and others, 1996). Samples of tuff from Lauro Canyon Dam, Rocky Nook Park, and Conejo Drive in Santa Barbara are undated but are petrographically and geochemically indistinguishable from each other (A.M. Sarna-Wojcicki, USGS, written commun., 2002) and probably were derived from the same eruptive source.

The age of the Rincon Shale is early Miocene on the basis of abundant biostratigraphic evidence from a measured stratigraphic section in Cañada de la Pila, about $15 \mathrm{~km}$ west of the map area (Stanley and others, 1992, 1994) and isotopic ages of tuffs, as noted above. Also, the base of the Rincon Shale is considered to be coincident with the Oligocene-Miocene boundary (D. Bukry, USGS, oral commun., 1994). The Rincon Shale rests abruptly and conformably on the upper Oligocene Vaqueros Formation and is conformably overlain by the middle and lower Miocene lower calcareous unit of the Monterey Formation.

Unit was previously mapped as Rincon Formation by Lian (1954) and as Rincon Shale by Upson (1951) and Dibblee (1966, 1986a, 1986b, 1987a, 1987b). The Rincon Shale is about $449 \mathrm{~m}$ thick at Cañada de la Pila (Stanley and others, 1992), about $400 \mathrm{~m}$ thick at Carneros and Las Vegas Creeks in the Goleta quadrangle, and about 430-460 m thick in the Santa Barbara quadrangle. Organic contents in the Rincon Shale are generally high enough for the unit to qualify as an important potential hydrocarbon source in the region (Tennyson and Isaacs, 2001). The unit is generally poorly exposed and covered by vegetation, and it is susceptible to landsliding (Bezore and Wills, 2000); for example, in the Sycamore Canyon area where significant and locally damaging downslope movement of Rincon debris has occurred. Along the coast, the Rincon Shale is well-exposed in sea cliffs but is generally less resistant to erosion than rocks of the Monterey Formation 
Trs

Siliceous shale interval (lower Miocene)-Siliceous shale is pale-gray and light-tan on freshly broken surfaces, weathers white to pale-gray, thin-bedded, and hard. Unit is slightly more resistant than surrounding Rincon mudstones and resembles siliceous shale intervals within Monterey Formation. Where siliceous interval is differentiated in western, coastal part of map area (west of San Pedro Creek) unit is about $60 \mathrm{~m}$ stratigraphically below top of Rincon Shale and has a thickness of 35 to $45 \mathrm{~m}$

Vaqueros Formation (upper Oligocene) - Shallow-marine sandstone; tan, yellowish-tan, yellowish-gray, and greenish-gray, weakly to moderately indurated, and feldspathic. Unit is moderately to strongly resistant to erosion and locally forms prominent ledges, cliffs, and ridges; commonly weathers to light-tan, rounded sandstone outcrops and distinctive, light-tan, sandy soils; some outcrops exhibit cavernous weathering. Sandstone is primarily massive, thick bedded, and medium to coarse grained, but becomes finer grained upsection; massive sandstone is mostly bioturbated. Some sandstone intervals are very coarse grained and pebbly and others are rich in shell fragments. Sandstone locally contains planar to cross laminations and rare thin $(5-15 \mathrm{~mm})$ partings of gray siltstone and mudstone. Uppermost part contains well-defined, thinly laminated sandstone, siltstone, and mudstone interbeds. Sandstone in upper third of unit commonly is mottled tan and greenish gray; underlying sandstone has abundant orange to red staining and mottling. Fractures commonly contain iron-oxide minerals. In thin section, sandstone consists primarily of quartz and subordinate feldspar and lithic grains (mostly chert and felsic volcanic rock) in an argillaceous matrix or calcite cement. The base of unit is typically marked by a distinctive $50-150-\mathrm{cm}-$ thick, well-indurated and flaggy, thinly bedded and laminated, light-gray, calcareous conglomerate containing abundant pelecypod-shell fragments, rounded chert pebbles, and subangular graywacke clasts as long as about $1 \mathrm{~cm}$; chert and graywacke are thought to be derived from the north from Franciscan Complex terrane (Rigsby, 1998). This conglomerate, which is locally as much as $5 \mathrm{~m}$ above the base of the Vaqueros, is well exposed at several outcrops in the foothills north of Goleta Valley.

The basal contact is sharp and recognized by abrupt change from thick, tan-yellow sandstone and basal gray, shell-rich conglomerate of the marine Vaqueros to underlying interbedded pale-greenish-gray, tabular sandstone and maroon to olive-gray mudstone of the nonmarine Sespe. Howard (1995) considered the lower Vaqueros contact to be an erosional disconformity throughout the map area, but Rigsby (1998) interpreted an eastward transition of the contact to conformable near Lauro Canyon.

Late Oligocene age is inferred from stratigraphic position of unit between the upper Oligocene upper part of the Sespe Formation and lower Miocene Rincon Shale. The base of the overlying Rincon Shale is considered to be coincident with the Oligocene-Miocene boundary (D. Bukry, oral commun., 1994). Rigsby (1998) reported a strontium-isotope date of $24 \pm 1$ Ma from oyster shells in Vaqueros Formation in the Hollister Ranch area 40 $\mathrm{km}$ west of map area, consistent with late Oligocene age.

Unit was previously mapped as basal Vaqueros Formation by Arnold (1907) and Vaqueros Sandstone by Upson (1951), Lian (1954), and Dibblee (1966, 1986a, 1986b, 1987a, 1987b). In the map area, unit gradually decreases in thickness eastward, from more than $150 \mathrm{~m}$ in the Dos Pueblos Canyon area to about $75 \mathrm{~m}$ in the Summerland area; a regional thickness of about $100 \mathrm{~m}$ was reported by Dibblee (1982). Some oil in the region is produced from Vaqueros sandstone reservoirs (Tennyson and Isaacs, 2001)

Sespe Formation (Oligocene and upper Eocene)—Nonmarine, fluvial sandstone, mudstone, and conglomerate; predominantly maroon, reddish-brown, and greenish- to pinkish-gray. Sespe Formation is poorly to moderately exposed primarily in northern part of map area in foothills of the Santa Ynez Mountains and in uplands north of Summerland and Carpinteria. In map area, Sespe Formation is divided into three subunits that are distinguished from each other mainly by differences in lithology, provenance, and age: an upper sandstone and mudstone unit (Tspu), a middle conglomerate and sandstone unit (Tspm), and a lower conglomerate and sandstone unit (Tspl). A major distinguishing feature of the upper unit is its lack of conglomerate, whereas the conglomeratic middle and lower units are distinguished mainly by their differing clast compositions and colors of weathered sandstone and conglomerate beds (mostly maroonish shades in middle unit and pinkish-gray shades 
in lower unit). The upper unit comprises well over half of the total thickness of formation, and in a few places in the central and western parts of map area the lower two units pinch out so that the upper Sespe rests directly on rocks of the underlying Coldwater Sandstone (Tcw). Overall thickness of Sespe Formation increases eastward from about $700 \mathrm{~m}$ near Tecolote Canyon to more than $1,500 \mathrm{~m}$ in the Summerland area. Some oil in the region is produced from Sespe sandstone and conglomerate reservoirs (Tennyson and Isaacs, 2001).

Age of Sespe Formation in Santa Barbara area is considered late Eocene and Oligocene by Howard (1995), with an intraformational unconformity representing much or all of early Oligocene time. This unconformity (erosional disconformity) coincides with the mapped contact separating the lower conglomerate and sandstone unit (Tspl) from the middle conglomerate and sandstone unit (Tspm). Rocks below unconformity have been interpreted as part of a upper Eocene to lowermost Oligocene fluvial sequence composed of clastic detritus derived primarily from bedrock now exposed in the Mojave Desert, whereas overlying rocks have been interpreted as part of a lower(?) and upper Oligocene fluvial sequence containing chert, graywacke, and other clasts derived from Franciscan Complex source terrane(s) (Howard, 1995)

Tspu Upper sandstone and mudstone unit (upper Oligocene)—Sandstone, siltstone, and mudstone interbedded in proportions that vary both laterally and through the section; sandstone to mudstone-siltstone ratio in a given exposure typically ranges from $\sim 5: 1$ to $\sim 1: 5$. Sandstone-rich units are commonly broadly lenticular and thin to thick bedded, and in places they appear to occupy paleochannels. Sandstone beds are as thick as $10 \mathrm{~m}$ but mostly less than $2 \mathrm{~m}$. Sandstone is mostly fine to medium grained, silty, feldspathic, and locally arkosic. On weathered surfaces, sandstones display various shades of maroon, buff, pale green, tan, and gray. Horizontal lamination and cross lamination, including trough cross lamination, are common. Sandstone is friable to well indurated and typically forms resistant tabular, flaggy, or ledgy outcrops. Small pebbly lenses are locally present in sandstone beds, and some thin ( $\leq 1 \mathrm{~m}$ thick) intervals, commonly near the base of beds, contain subrounded mudstone rip-up clasts as long as $30 \mathrm{~cm}$.

Mudstone is typically silty to sandy and locally grades into siltstone and, rarely, fine-grained sandstone. Mudstone and siltstone are typically maroon, reddish maroon, and brownish maroon, but in some places they are pale green or olive green. Mudstone is thin to very thin bedded and commonly laminated. Intervals of nearly pure mudstone range from less than $10 \mathrm{~cm}$ to at least $10 \mathrm{~m}$ thick. Mudstone and siltstone bedding planes commonly contain mud cracks and ripple marks. Mudstone exhibits hackly to spheroidal fracturing on weathered surfaces. Most mudstone-rich intervals are poorly exposed and form gentle slopes.

Late Oligocene age of upper unit is based on Arikareean vertebrate fossils reported from the underlying middle unit in the map area (Weaver and Kleinpell, 1963; Howard, 1995) and on the Miocene-Oligocene boundary recognized at the base of the Rincon Shale (Tr) farther upsection (D. Bukry, oral commun., 1994).

Environment of deposition of Sespe upper sandstone and mudstone unit, which is equivalent to lithofacies " $\mathrm{D}$ " of Howard (1995), has been interpreted as progressing upward from braided to meandering river channels and interchannels (Howard, 1995). Unit was previously mapped as part of the Sespe Formation by Upson (1951), Lian (1954), and Dibblee (1966, 1986a, 1986b, 1987a, 1987b). Upper unit thickens eastward across map area from about $500 \mathrm{~m}$ in the Eagle Canyon area to more than 1,000 m north of Summerland. Upper Sespe unit is prone to landsliding, particularly on steeper slopes along the lower flanks of the Santa Ynez Mountains, as evidenced by numerous slumps and lesser debris-flow deposits in such areas

Tspm Middle conglomerate and sandstone unit (Oligocene)—Conglomerate, sandstone, and mudstone interbedded in proportions that vary both laterally and through the section; relative proportion of conglomerate increases downsection towards base of unit, but conglomerate is strongly subordinate to sandstone and mudstone in some intervals. Conglomeratic depositional units range from laterally extensive to narrowly lenticular and thin to thick bedded (as thick as $15 \mathrm{~m}$ ), and in some places they appear to occupy paleochannels. Conglomerate and conglomeratic sandstone typically contain subangular to well-rounded 
pebbles and cobbles supported in a medium- to coarse-grained sandy matrix. Clasts are polymict and include abundant chert and lithic sandstone derived from Franciscan Complex terrane(s), arkosic sandstone derived from Coldwater Sandstone, and quartzitic, metamorphic, and granitoid rocks derived from Mojave Desert terrane(s) (Howard, 1995). Sandstone is mostly medium to coarse grained, pebbly, silty, and feldspathic to lithic; rare sandstone beds are arkosic. On weathered surfaces, conglomerates and sandstones display various shades of maroon and, less commonly, tan and pale greenish gray. Horizontal lamination and cross lamination, including trough cross lamination, are common, particularly in sandstones. Sediment-filled fossil burrows are apparent on some sandstone bedding planes. Commonly, conglomerates and sandstones are moderately indurated and resistant and form tabular, flaggy, or ledgy outcrops.

Mudstone is typically silty to sandy and locally grades into siltstone and, more rarely, fine-grained sandstone. Mudstone is thin to very thin bedded and commonly laminated. Ripple marks are common. Mudstone-rich intervals range in thickness from thin partings to $20 \mathrm{~m}$. Mudstone is maroon, maroonish red, reddish brown, and, rarely, pale greenish gray and exhibits hackly to spheroidal fracturing on weathered surfaces. Most mudstone-rich intervals are poorly exposed and form gentle slopes.

Upper contact of middle unit mapped at stratigraphically highest conglomerate bed. Disconformity at base of middle unit commonly expressed by abrupt change from maroonish sandstone and conglomerate of mixed provenance (middle unit) to pale-pinkish-gray sandstone and conglomerate of largely granitic and metamorphic provenance (lower Sespe unit).

Middle conglomerate and sandstone unit is primarily equivalent to Sespe lithofacies " $C$ " of Howard (1995). Oligocene age of middle unit is based on Arikareean vertebrate fossils (Sespia nitida Leidy) that were reported from the unit above unconformity along San Marcos Pass highway and in Sycamore Canyon (Weaver and Kleinpell, 1963; Howard, 1995).

Middle unit was previously mapped as part of the Sespe Formation by Upson (1951), Lian (1954), and Dibblee (1966, 1986a, 1986b, 1987a, 1987b), and as red to gray conglomerate and arkosic sandstone of the Sespe Formation by Dibblee (1987b). Middle unit generally increases in thickness eastward in map area from where it pinches out in Tecolote Canyon to about $200 \mathrm{~m}$ in San Pedro Canyon, to $335 \mathrm{~m}$ in Sycamore Canyon, to almost $450 \mathrm{~m}$ thick north of Carpinteria, but unit locally pinches out over a strike distance of more than $1.8 \mathrm{~km}$ in the north-central part of area. Unit is moderately susceptible to landsliding particularly on steeper slopes along the lower flanks of the Santa Ynez Mountains as evidenced by several slumps in such areas

Tspl Lower conglomerate and sandstone unit (lower Oligocene? and upper Eocene) - Conglomerate, conglomeratic sandstone, sandstone, mudstone, and minor shale interbedded in proportions that vary both laterally and through the section. Conglomeratic depositional units range from laterally extensive to narrowly lenticular and medium to thick bedded (as thick as $15 \mathrm{~m}$ ), and in some places they appear to occupy paleochannels. Conglomerate and conglomeratic sandstone typically contain pebbles and cobbles as much as $50 \mathrm{~cm}$ in diameter supported in a medium-grained to very coarse-grained, locally arkosic sandstone matrix. Clasts are polymict and include abundant subrounded to well-rounded quartzitic, granitoid, metamorphic, and volcanic clasts derived from Mojave Desert source terrane(s) and lesser subangular to subrounded arkosic sandstone clasts and rare oyster-shell fragments and shale clasts derived from Coldwater Sandstone (Tcw) (Howard, 1995). Sandstone is mostly medium to very coarse grained, pebbly, feldspathic, and locally arkosic. On weathered surfaces, conglomerates and sandstones mostly exhibit distinctive shades of salmon gray, reddish gray, pale-pinkish gray, and tan, but some beds are pale gray, maroon, or brown; reddish-brown iron-oxide staining is locally prevalent. Horizontal lamination and cross lamination, including trough cross lamination, are very common, particularly in sandstones. Conglomerates and sandstones are moderately to well indurated, resistant, and form flaggy, blocky, and ledgy outcrops and hogbacks.

Mudstone is typically silty to sandy and locally grades into siltstone and, more rarely, fine-grained sandstone. Intervals of fissile shale are locally present. Mudstone is thin to 
very thin bedded and commonly laminated. Mudstone-rich intervals range in thickness from thin partings to $5 \mathrm{~m}$. Mudstone is maroon, maroonish red, gray, greenish-gray, and reddish brown and exhibits hackly to spheroidal fracturing on weathered surfaces. Most mudstone-rich intervals are poorly exposed and form gentle slopes.

Disconformable upper contact of lower conglomerate and sandstone unit mapped at top of 3- to 10-m-thick interval of conspicuous deep-reddish-brown, massive-to-bedded, silty to sandy claystone and mudstone. Basal, mostly conformable, contact of lower unit mapped at generally sharp change from pinkish- and reddish-gray, laminated sandstone and conglomerate (Sespe) to pale yellow-tan to buff, massive, commonly oyster-shellbearing sandstone of the underlying Coldwater Sandstone (Tcw). Locally in eastern map area lower contact is gradational, expressed by a thin $(<10 \mathrm{~m})$ to thick $(>10 \mathrm{~m})$ interval of Coldwater-like sandstone containing Sespe-like maroon mudstone and siltstone interbeds; in such areas basal Sespe contact mapped at top of uppermost Coldwater-like sandstone bed.

Overall grain size of lower unit becomes finer in northwest part of map area, and at Bartlett Canyon, lower unit has been previously interpreted to grade westward into marine sandstone of the upper Eocene and lowermost Oligocene (Refugian) Gaviota Formation (Weaver and Kleinpell, 1963; Howard, 1995). However, correlation of lower Sespe beds with Gaviota in this area is questionable due to fault complications (as noted in Weaver and Kleinpell, 1963) and because unequivocal marine, fossil-bearing interbeds were not observed within the lower unit during our mapping. Possibly the lower Sespe transition into the Gaviota is confined to the small area where the lower conglomerate and sandstone unit pinches out in Glen Annie Canyon. The locally gradational nature of the basal Sespe contact with the underlying Coldwater Sandstone is consistent with a late Eocene age for part or all of the lower conglomerate and sandstone unit.

The lower unit is primarily equivalent to Sespe lithofacies "A" of Howard (1995). Unit was previously mapped as part of the Sespe Formation by Upson (1951) and Dibblee (1966, 1986a, 1986b, 1987a, 1987b), as the lower member of the Sespe Formation by Lian (1954), and as red to pink (or pink to white) sandstone and red claystone of the Sespe Formation by Dibblee (1986a, 1986b, 1987b). The lower conglomerate and sandstone unit generally increases in thickness eastward along strike in map area from where it pinches out in Glen Annie Canyon to about 170 m north of Santa Barbara; farther eastward unit gradually thins to $100 \mathrm{~m}$ north of Montecito but then locally thickens to more than $250 \mathrm{~m}$ north of Carpinteria; unit also pinches out along a short strike distance near Barger Canyon in north-central map area

Tcw Coldwater Sandstone (upper? and middle Eocene)—Shallow-marine sandstone with subordinate interbeds and thin intervals of siltstone, shale, and mudstone. Sandstone is mostly fine- to medium-grained, feldspathic and partly arkosic, locally silty to clayey or micaceous, and locally weakly cemented with calcium carbonate. Sandstone forms thin, tabular beds as well as medium to thick beds, some of which are massive and bioturbated, whereas others contain planar, wavy, or cross laminations. Thin siltstone and shale partings are rare in the sandstones. Sandstone is typically pale gray and greenish gray on fresh surfaces and weathers to distinctive, pale shades of buff, yellowish-tan, tan, and brown. Some beds and intervals as thick as $3 \mathrm{~m}$, especially in the upper part of the unit, contain rare to conspicuously abundant oyster shells and shell fragments (Ostrea idriaensis, Weaver and Kleinpell, 1963), and numerous other fossil mollusks have been previously identified throughout the unit (for example, Weaver and Kleinpell, 1963). Other beds and intervals contain rare to abundant ferruginous(?) fossil wood fragments that commonly contrast visually with the surrounding rock due to their dark-gray to reddish-brown color. Local lenses and intervals as thick as $25 \mathrm{~m}$ of conglomeratic sandstone are present in the uppermost Coldwater near its contact with the overlying lower unit of the Sespe Formation (Tspl). Evidence of localized soft-sediment deformation consists of contorted and disrupted layering in some sandstone beds. Sandstone beds and sandstone-rich intervals typically crop out as resistant, blocky ledges and cliffs and form prominent hogbacks where steeply dipping. 
Siltstone, shale, and mudstone form interbeds as thin as $1 \mathrm{~cm}$ and bedded intervals as thick as $5 \mathrm{~m}$. These fine-grained rocks mostly exhibit pale to dark shades of gray, olivegray, and greenish-gray. Commonly shale is fissile and mudstone exhibits hackly fractures. Some siltstone beds are micaceous and contain fossil wood fragments. Siltstones and finergrained rocks of the Coldwater are considerably less resistant and more poorly exposed than the sandstones.

Some siltstone and mudstone intervals in uppermost part of unit in eastern part of map area are maroon, suggesting that contact with overlying nonmarine beds of the Sespe Formation becomes gradational to the east. In such areas, upper Coldwater contact is mapped at top of uppermost Coldwater-like sandstone bed.

Age of unit is not tightly constrained in map area; regionally, age of Coldwater has been variably considered late and (or) middle Eocene (Narizian) (Kleinpell and Weaver, 1963; Dibblee, 1966; Howard, 1995; Campion and others, 1996; Prothero, 2001) on basis of paleontologic, magnetostratigraphic, and sequence stratigraphic correlations. Uppermost part of map unit in northwest part of map area may include eastward-terminating sandstone-rich beds of the marine, upper Eocene and lowermost Oligocene (Refugian) Gaviota Formation that closely resemble sandstones of the underlying Coldwater (Weaver and Kleinpell, 1963; Dibblee, 1966, 1987a).

Unit was previously mapped as Tejon Formation by Upson (1951), as "Coldwater" Sandstone by Dibblee (1966), and as Coldwater Sandstone by Lian (1954) and Dibblee (1986a, 1986b, 1987a, 1987b). Base of Coldwater is not exposed in map area; unit is about 750 to $1,000 \mathrm{~m}$ thick regionally (Dibblee, 1982). Unit forms elevated, rugged ridges, spurs, and hogbacks on the steep, southern flank of the Santa Ynez Mountains. Several large landslide deposits in the Coldwater in the map area indicate susceptibility of the unit to slope failure. 


\section{References Cited}

Addicott, W.O., 1965, Some western American Cenozoic gastropods of the genus Nassarius: U.S. Geological Survey Professional Paper 503B, p. B1-B21.

Anderson, L.W., 1999, Interim assessment of surface faulting potential at Lauro Dam, Cachuma Project, California: U.S. Bureau of Reclamation Technical Memorandum No. D8330-99-011, 18 p.

Arends, R.G., and Blake, G.H., 1986, Biostratigraphy and paleoecology of the Naples Bluff coastal section based on diatoms and benthic foraminifera, in Casey, R.E., and Barron, J.A., eds., Siliceous microfossil and microplankton studies of the Monterey Formation and modern analogs: Los Angeles, Society of Economic Paleontologists and Mineralogists, Pacific Section, Book 45, p. 121-135.

Arnold, Ralph, 1907, Geology and oil resources of the Summerland district, Santa Barbara County, California: U.S. Geological Survey Bulletin, no. 321, 93 p.

Atwater, Tanya, and Stock, Joann, 1998, Pacific-North America plate tectonics of the Neogene southwestern United Statesan update: International Geology Review, v. 40, p. 375-402.

Bailey, T.L., 1952, Review [of"Geology of Southwestern Santa Barbara County, California," by T.W. Dibblee, Jr.]: American Association of Petroleum Geologists Bulletin, v. 36, no. 1, p. 176-178.

Barron, J.A., 1986, Updated diatom biostratigraphy for the Monterey Formation of California, in Casey, R.E., and Barron, J.A., eds., Siliceous microfossil and microplankton studies of the Monterey Formation and modern analogs: Society of Economic Paleontologists and Mineralogists, Pacific Section, Book 45, p. 105-119.

Bezore, Stephen, and Wills, C.J., 2000, Landslide hazard maps of southeastern Santa Barbara County, California: California Division of Mines and Geology Open-File Report 99-12, 4 sheets, scale 1:24,000.

Blake, G.H., 1994, Detailed biostratigraphy and paleoenvironmental interpretation of the Naples Bluff section, in Hornafius, J.S., ed., Field guide to the Monterey Formation between Santa Barbara and Gaviota, California: Bakersfield, Calif., Pacific Section, American Association of Petroleum Geologists, p. 17-28.

Bohacs, K.M., and Schwalbach, J.R., 1994, Natural gammaray spectrometry of the Monterey Formation at Naples Beach, California: insights into lithology, stratigraphy, and source-rock quality, in Hornafius, J.S., ed., Field guide to the Monterey Formation between Santa Barbara and Gaviota, California: Bakersfield, Calif., Pacific Section, American Association of Petroleum Geologists, p. 85-94.
Campion, K.M., Sullivan, M.D., May, J.A., and Warme, J.E., 1996, Sequence stratigraphy along a tectonically active margin, Paleogene of southern California, in Abbott, P.L., and Cooper, J.D., eds., Field Conference Guide 1996: American Association of Petroleum Geologists, Pacific Section, GB 73, and Society for Sedimentary Geology (SEPM), Pacific Section, Book 80, p. 125-187.

Cruden, D.M., and Varnes, D.J., 1996, Landslide types and processes, in Turner, A.K., and Schuster, R.L., eds., Landslides: investigation and mitigation: Washington, D.C., National Academy Press, p. 36-75.

Dalrymple, G.B., 1979, Critical tables for conversion of $\mathrm{K}-\mathrm{Ar}$ ages from old to new constants: Geology, v. 7, no. 11, p. $558-560$.

DePaolo, D.J., and Finger, K.L., 1991, High-resolution strontium-isotope stratigraphy and biostratigraphy of the Miocene Monterey Formation, central California: Geological Society of America Bulletin, v. 103, no. 1, p. 112-124.

Dibblee, T.W., Jr., 1950, Geology of southwestern Santa Barbara County, California: California Division of Mines and Geology Bulletin 150, 84 p.

Dibblee, T.W., Jr., 1966, Geology of the central Santa Ynez Mountains, Santa Barbara County, California: California Division of Mines and Geology Bulletin 186, 99 p.

Dibblee, T.W., Jr., 1982, Geology of the Santa Ynez-Topatopa Mountains, Southern California, in Fife, D.L., and Minch, J.A., eds., Geology and mineral wealth of the California Transverse Ranges: Santa Ana, California, South Coast Geological Society Annual Symposium and Guidebook no. 10 , p. 41-56.

Dibblee, T.W., Jr., 1986a, Geologic map of the Carpinteria quadrangle, Santa Barbara County, California: Santa Barbara, Dibblee Geological Foundation Map DF-04, scale $1: 24,000$.

Dibblee, T.W., Jr., 1986b, Geologic map of the Santa Barbara quadrangle, Santa Barbara County, California: Santa Barbara, Dibblee Geological Foundation Map DF-06, scale $1: 24,000$.

Dibblee, T.W., Jr., 1987a, Geologic map of the Dos Pueblos quadrangle, Santa Barbara County, California: Santa Barbara, Dibblee Geological Foundation Map DF-09, scale $1: 24,000$.

Dibblee, T.W., Jr., 1987b, Geologic map of the Goleta quadrangle, Santa Barbara County, California: Santa Barbara, Dibblee Geological Foundation Map DF-07, scale 1:24,000.

Dickinson, W.R., 1969, Geologic problems in the mountains between Ventura and Cuyama, in Dickinson, W.R., ed., Upper Sespe Creek: Society of Economic Paleontologists and Mineralogists (SEPM), Pacific Coast Section, 96 Field Trip Guidebook, p. 1-23. 
Dickinson, W.R., 1995, Paleogene depositional systems of the western Transverse Ranges and adjacent southernmost Coast Ranges, California, in Fritsche, A.E., ed., Cenozoic Paleogeography of the western United States II: Santa Fe Springs, Calif., Pacific Section SEPM (Society for Sedimentary Geology), p. 53-83.

Dickinson, W.R., 1996, Kinematics of transrotational tectonism in the California Transverse Ranges and its contribution to cumulative slip along the San Andreas transform fault system: Geological Society of America Special Paper $305,46 \mathrm{p}$.

Föllmi, K.B., Badertscher, Christophe, de Kaenel, Eric, Stille, Peter, John, C.M., Adatte, Thierry, and Steinmann, Philipp, 2005, Phosphogenesis and organic-carbon preservation in the Miocene Monterey Formation at Naples Beach, California - the Monterey hypothesis revisited: Geological Society of America Bulletin, v. 117, no. 5/6, p. 589-619.

Garrison, R.E., Hoppie, B.W., and Grimm, K.A., 1994, Phosphates and dolomites in coastal upwelling sediments of the Peru margin and the Monterey Formation (Naples Beach section), California, in Hornafius, J.S., ed., Field guide to the Monterey Formation between Santa Barbara and Gaviota, California: Bakersfield, Calif., Pacific Section, American Association of Petroleum Geologists, p. 67-84.

Garrison, R.E., and Ramirez, P.C., 1989, Conglomerates and breccias in the Monterey Formation and related units as reflections of basin margin history, in Colburn, I.P., Abbott, P.L., and Minch, John, eds., Conglomerates in basin analysis: a symposium dedicated to A.O. Woodford: Bakersfield, Calif., Pacific Section, Society of Economic Paleontologists and Mineralogists, Book 62, p. 189-206.

Gross, M.R., Gutierrez-Alonso, Gabriel, and Bartlett, W.L., 1998, Fold-related fractures in coastal outcrops of the Monterey Formation: Effects of structural style, mechanical stratigraphy, and scale at Arroyo Burro Beach, in Eichhubl, Peter, ed., Diagenesis, deformation, and fluid flow in the Miocene Monterey Formation: Pacific Section, Society of Economic Paleontologists and Mineralogists, Book 83, p. 37-65.

Gurrola, L.D., Selting, A.J., Keller, E.A., Tierney, T.E., Hartleb, R.D., Trecker, M.A., and Dibblee, T.W., Jr., 2001, Neotectonics of the Santa Barbara fold belt, California, with a section on Investigation of the Mission debris flow deposit, Santa Barbara, California, by A.J. Selting, and R.J. Urban, in Dunne, George, and Cooper, John, compilers, Geologic excursions in southwestern California: Pacific Section, Society of Economic Paleontologists and Mineralogists, Book 89, p. 21-100.

Hill, M.L., 1932, Mechanics of faulting near Santa Barbara, California: Journal of Geology, v. 40, no. 6, p. 535-556.
Hoover, M.F., 1978, Geologic hazards evaluation of the City of Santa Barbara in Santa Barbara Seismic Hazard Report, Santa Barbara, Calif., Michael F. Hoover, Consulting Geologist, 35 p.

Hornafius, J.S., 1991, Facies analysis of the Monterey Formation in the northern Santa Barbara channel: American Association of Petroleum Geologists Bulletin, v. 75, no. 5, p. 894-909.

Hornafius, J.S., 1994a, Field trip road log to the Monterey Formation between Santa Barbara and Gaviota, California, in Hornafius, J.S., ed., Field guide to the Monterey Formation between Santa Barbara and Gaviota, California: Bakersfield, Calif., Pacific Section, American Association of Petroleum Geologists, p. 107-123.

Hornafius, J.S., 1994b, Overview of the stratigraphy of the Monterey Formation along the coastline between Santa Barbara and Gaviota, California, in Hornafius, J.S., ed., Field guide to the Monterey Formation between Santa Barbara and Gaviota, California: Bakersfield, Calif., Pacific Section, American Association of Petroleum Geologists, p. 1-15.

Hornafius, J.S., Luyendyk, B.P., Terres, R.R., and Kamerling, M.J., 1986, Timing and extent of Neogene tectonic rotation in the western Transverse Ranges, California: Geological Society of America Bulletin, v. 97, p. 1476-1487.

Howard, J.L., 1995, Conglomerates of the upper middle Eocene to lower Miocene Sespe Formation along the Santa Ynez Fault-Implications for the geologic history of the eastern Santa Maria basin area, California: U.S. Geological Survey Bulletin 1995-H, p. H1-H36.

Ingle, J.C., Jr., 1980, Cenozoic paleobathymetry and depositional history of selected sequences within the southern California continental borderland: Cushman Foundation Special Publication 19, Memorial to Orville Bandy, p. 163-195.

Izett, G.A., Naeser, C.W., and Obradovich, J.D., 1974, Fissiontrack age of zircons from an ash bed in the Pico Formation (Pliocene and Pleistocene) near Ventura, California [abs.]: Geological Society of America, Annual Meeting, Cordilleran Section, Abstracts with Program, p. 197.

Jackson, P.J., and Yeats, R.S., 1982, Structural evolution of Carpinteria basin, western Transverse Ranges, California: American Association of Petroleum Geologists Bulletin, v. 66, p. 805-829.

Keller, E.A., Gurrola, Larry, and Tierney, T.E., 1999, Geomorphic criteria to determine direction of lateral propagation of reverse faulting and folding: Geology, v. 27, no. 6, p. 515-518. 
Keller, E.A., and Gurrola, L.D., 2000, Final report, July, 2000, Earthquake hazard of the Santa Barbara fold belt, California. (available online at: http://www.scec.org/research/98research/ 98gurrolakeller.pdf)

Keller, M.A. (ed.), Evolution of sedimentary basins/onshore oil and gas investigations - Santa Maria province: U.S. Geological Survey Bulletin 1995-T, p. T1-T18.

Kennedy, G.L., Lajoie, K.R., and Wehmiller, J.F., 1982, Aminostratigraphy and faunal correlations of late Quaternary marine terraces, Pacific Coast, USA: Nature, v. 299, no. 5883 , p. 545-547.

Kleinpell, R.M., 1938, Miocene stratigraphy of California: Tulsa, Okla., American Association of Petroleum Geologists, v. SP 9, 450 p.

Kleinpell, R.M., 1980, History of stratigraphic paleontology of west coast Tertiary, in Kleinpell, R.M., The Miocene stratigraphy of California revisited: Tulsa, Okla., American Association of Petroleum Geologists, Studies in Geology no. 11, p. 4-53.

Kleinpell, R.M., and Weaver, D.W., 1963, Oligocene biostratigraphy of the Santa Barbara embayment, California: University of California Publications in Geological Sciences, v. 43, $250 \mathrm{p}$.

Lian, H.M., 1954, Geology of the Carpinteria district, Santa Barbara County, in Geology of southern California: California Division of Mines and Geology Bulletin 170, map sheet 25.

Luyendyk, B.P., 1991, A model for Neogene crustal rotations, transtension, and transpression in southern California: Geological Society of America Bulletin, v. 103, no.11, p. 1528-1536.

McDougall, Kristin, and Lagoe, M.B., 1993, Foraminiferal data from the Balcom Canyon Section, Ventura Basin, California: U.S. Geological Survey Open-File Report 93-386, 132 pp.

Minor, S.A., Kellogg, K.S., Stanley, R.G., Stone, Paul, Powell, C.L., II, Gurrola, L.D., Selting, A.J., and Brandt, T.R., 2002; revised 2006, Preliminary geologic map of the Santa Barbara coastal plain area, Santa Barbara County, California: U.S. Geological Survey Open-File Report 02-0136, 22 p., scale 1:24,000. (Available online at: http://pubs.usgs.gov/of/2002/ ofr-02-0136/)

Molnar, Peter, and Gipson, J.M., 1994, Very long baseline interferometry and active rotations of crustal blocks in the western Transverse Ranges, California: Geological Society of America Bulletin, v. 106, no. 5, p. 594-606.

Muhs, D.R., Rockwell, T.K., and Kennedy, G.L., 1992, Late Quaternary uplift rates of marine terraces on the Pacific coasts of North America, southern Oregon to Baja California Sur: Quaternary International, v. 15-16, p. 121-133.
Muir, K.S., 1968, Ground-water reconnaissance of the Santa Barbara-Montecito area, Santa Barbara County, California: U.S. Geological Survey Water-Supply Paper 1859-A, 28 p.

Namson, J.S., and Davis, T.L., 1988, Structural transect of the western Transverse Ranges, California: Implications for lithospheric kinematics and seismic risk evaluation: Geology, v. 16, p. 675-679.

Natland, M.L., 1952, Pleistocene and Pliocene stratigraphy of southern California: Los Angeles, University of California, Ph.D. thesis, $165 \mathrm{p}$.

Nilsen, T.H., 1984, Oligocene tectonics and sedimentation, California: Sedimentary Geology, v. 38, p. 305-336.

Olson, D.J., 1982, Surface and subsurface geology of the Santa Barbara-Goleta metropolitan area, Santa Barbara County, California: Corvallis, Oregon, Oregon State University, M.S. thesis, $71 \mathrm{p}$.

Page, B.M., Thompson, G.A., and Coleman, R.G., 1998, Overview-Late Cenozoic tectonics of the central and southern Coast Ranges of California: Geological Society of America Bulletin, v. 110, no. 7, p. 846-876.

Patterson, R.T., Brunner, C.A., Capo, Rosemary, and Dahl, Jeremy, 1990, A paleoenvironmental study of early to middle Pleistocene foraminifera of the Santa Barbara Formation at Santa Barbara, California: Journal of Paleontology, v. 64, no. 1, p. 1-25.

Prothero, D.R., 2001, Magnetostratigraphic tests of sequence stratigraphic correlations from the Southern California Paleogene: Journal of Sedimentary Research, v. 71, no. 4, p. 526-536.

Rigsby, C.A., 1998, Paleogeography of the Western Transverse Range Province, California-New evidence for the late Oligocene and early Miocene Vaqueros Formation in Keller, M.A. (ed.), Evolution of sedimentary basins/onshore oil and gas investigations - Santa Maria province: U.S. Geological Survey Bulletin 1995-T, p. T1-T18.

Rockwell, T.K., Keller, E.A., Clark, M.N., and Johnson, D.L., 1984, Chronology and rates of faulting of Ventura River terraces, California: Geological Society of America Bulletin, v. 95, no. 12, p. 1466-1474.

Rockwell, T.K., Nolan, Jeff, Johnson, D.L., and Patterson, R.H., 1992, Ages and deformation of marine terraces between Point Conception and Gaviota, western Transverse Ranges, California, in Fletcher, C.H. III, and Wehmiller, J.F., eds., Quaternary coasts of the United States: Marine and Lacustrine systems: Society of Economic Paleontologists and Mineralogists Special Publication 48, p. 333-341. 
Stanley, R.G., Cotton, M.L., Bukry, David, Filewicz, M.V., Valin, Z.C., and Vork, D.R., 1994, Stratigraphic revelations regarding the Rincon Shale (lower Miocene) in the Santa Barbara coastal area, California [abs.]: American Association of Petroleum Geologists Bulletin, v. 78, no. 4, p. 675-676.

Stanley, R.G., Johnson, S.Y., Swisher, C.C., III, Mason, M.A., Obradovich, J.D., Cotton, M.L., Filewicz, M.V., and Vork, D.R., 1996, Age of the Lospe Formation (early Miocene) and origin of the Santa Maria basin, California: U.S. Geological Survey Bulletin 1995-M, p. M1-M37.

Stanley, R.G., Valin, Z.C., and Pawlewicz, M.J., 1992, RockEval pyrolysis and vitrinite reflectance results from outcrop samples of the Rincon Shale (lower Miocene) collected at the Tajiguas Landfill, Santa Barbara County, California: U.S. Geological Survey Open-File Report 92-571, 27 p.

Suppe, John, 1985, Principles of structural geology: Prentice Hall, Inc., Englewood Cliffs, New Jersey, 537 p.

Tan, S.S., and Clahan, K.B., 2004, Geologic map of the White Ledge Peak 7.5' quadrangle, Santa Barbara and Ventura Counties, California: A digital database: California Geological Survey Preliminary Geologic Map, scale 1:24,000. (Available online at: $h t t p: / / w w w . c o n s e r v a t i o n . c a . g o v / c g s /$ $\mathrm{rghm} / \mathrm{rgm} /$ preliminary_geologic_maps.htm)

Tchalenko, J.S., 1970, Similarities between shear zones of different magnitudes: Geological Society of America Bulletin, v. 81 , no. 6 , p. $1625-1640$.

Tennyson, M.E., and Isaacs, C.M., 2001, Geologic setting and petroleum geology of Santa Maria and Santa Barbara basins, coastal California, in Isaacs, C.M., and Rullkotter, Jurgen, eds., The Monterey Formation-From rocks to molecules: Columbia University Press, New York, p. 206-229.

Turner, D.L., 1970, Potassium-argon dating of Pacific coast Miocene foraminiferal stages, in Bandy, O.L., ed., Radiometric dating and paleontologic zonation: Geological Society of America Special Paper 124, p. 91-129.

U.S. Geological Survey Geologic Names Committee, 2007, Divisions of geologic time-major chronostratigraphic and geochronologic units: U.S. Geological Survey Fact Sheet 2007-3015, 2 p.

Publishing support provided by:

Denver Publishing Service Center

For more information concerning this publication, contact

Team Chief Scientist, USGS Earth Surface Processes

Box 25046, Mail Stop 980

Denver, CO 80225

(303) 236-5344

Or visit the Earth Surface Processes Team Web site at: http://esp.cr.usgs.gov
Upson, J.E., 1951, Geology and ground-water resources of the south-coast basins of Santa Barbara County, California: U.S. Geological Survey Water-Supply Paper 1108, 144 p.

Urban, R.J., 2004, The Mission diamicton and associated geohazards, Santa Barbara, California: San Jose, California State University, M.S. thesis, 210 p.

Valentine, J.W., 1961, Paleoecologic molluscan geography of the California Pleistocene: University of California Publications in Geological Sciences, v. 34, no. 7, p. 309-442.

Weaver, D.W., and Kleinpell, R.M., 1963, Oligocene biostratigraphy of the Santa Barbara embayment, California, Part II, Mollusca from the Turritella variata zone and their chronologic and biogeographic significance: University of California, Publications in the Geological Sciences, v. 43, p. 80-161.

Wehmiller, J.F., 1992, Aminostratigraphy of southern California Quaternary marine terraces, in Fletcher, C.H. III, and Wehmiller, J.F., eds., Quaternary coasts of the United States: marine and lacustrine systems: SEPM (Society for Sedimentary Geology) Special Publication 48, p. 317-321.

Williams, Howel, Turner, F.J., and Gilbert, C.M., 1982, Petrography: an introduction to the study of rocks in thin sections (2d ed.): San Francisco, W.H. Freeman and Company, $626 \mathrm{p}$.

Willis, Bailey, 1925, A study of the Santa Barbara earthquake of June 29, 1925: Seismological Society of America Bulletin, v. 15 , no. 4, p. 255-278, fault map.

Wright, R.H., 1972, Late Pleistocene marine fauna, Goleta, California: Journal of Paleontology, v. 46, no. 5, p. 688695.

Yerkes, R.F., and Lee, W.H.K., 1987, Late Quaternary deformation in the western Transverse Ranges, in Morton, D.M., and Yerkes, R.F., eds., Recent reverse faulting in the Transverse Ranges, California: U.S. Geological Survey Professional Paper 1339, p. 71-82.

Yerkes, R.F., Sarna-Wojcicki, A.M., and Lajoie, K.R., 1987, Geology and Quaternary deformation of the Ventura area, in Morton, D.M., and Yerkes, R.F., eds., Recent reverse faulting in the Transverse Ranges, California: U.S. Geological Survey Professional Paper 1339, p. 169-178. 
